\title{
The importance of phospholipids combined with long-chain PUFA in formulated diets for pikeperch (Sander lucioperca) larvae
}

\author{
Ivar Lund $^{1}{ }^{*}$, Najlae El Kertaoui ${ }^{2} \dagger$ Marisol S. Izquierdo ${ }^{3}$, David Dominguez ${ }^{3}$, Benni W. Hansen ${ }^{4}$ and \\ Patrick Kestemont ${ }^{2}$ \\ ${ }^{1}$ Technical University of Denmark, DTU Aqua, Section for Aquaculture, The North Sea Research Centre, PO Box 101, \\ DK-9850 Hirtshals, Denmark \\ ${ }^{2}$ Research Unit in Environmental and Evolutionary Biology, University of Namur, Rue de Bruxelles, 61-5000 Namur, Belgium \\ ${ }^{3}$ Grupo de Investigación en Acuicultura (GIA), Instituto Universitario Ecoaqua, Universidad de Las Palmas de Gran Canaria, \\ Crta. Taliarte s/n, 35214 Telde, Spain \\ ${ }^{4}$ Department for Science and Environment, Roskilde University, 4000 Roskilde, Denmark
}

(Submitted 15 December 2017 - Final revision received 31 May 2018 - Accepted 1 June 2018 - First published online 30 July 2018)

\section{Abstract}

Dietary phosphoglycerides and $n$-3 long-chain PUFA (LC-PUFA) play important functions in the development of pikeperch (Sander lucioperca) larvae. This study aimed to determine optimal dietary levels of soyabean lecithin (SBL)-derived phospholipids (PL) in starter feeds for pikeperch larvae 10-30 d post-hatch (DPH) and examine performance and ontogeny by additional supplementation of $n$-3 LC-PUFA in the form of Algatrium DHA 70 (glyceride product; $660-700 \mathrm{mg} / \mathrm{g}$ DHA; EPA $60-75 \mathrm{mg} / \mathrm{g}$ ). In total, six isoproteic and isoenergetic extruded diets were formulated with increasing levels of PL (3.7, 8.3 or $14.5 \%$ wet weight (w.w.), respectively); however, three of the diets were supplemented with three levels of Algatrium DHA 70 (0.6, $2 \cdot 0$ or 3.4\%, respectively). Liver proteomic analyses of larvae at 30 DPH were included for effects of PL and primarily DHA on performance, physiological expression and interactions in larval proteins. In addition, bone anomalies, digestive enzymatic activity, candidate gene expression and skeleton morphogenesis were examined. Results confirmed the importance of dietary PL levels of at least $8.2 \%$ w.w., and an additional beneficiary effect of supplementation with DHA plus EPA. Thus, combined supplementation of SBL (up to $14.51 \%$ w.w. PL) and $n$-3 LC-PUFA (1.004\% DM DHA and $0 \cdot 169 \%$ DM EPA) in the form of TAG resulted in highest growth and lowest incidence of anomalies, improved digestive enzyme activity and had differential effect on liver proteomics. The results denote that essential fatty acids can be supplemented as TAG to have beneficial effects in pikeperch larvae development.

Key words: Sander lucioperca: Phospholipids: Long-chain PUFA: DHA: Performance: Proteomic expression: Abnormalities

Pikeperch (Sander lucioperca) is a freshwater species of high commercial interest in aquaculture with an increasing production in intensive recirculation systems ${ }^{(1)}$. Tailored commercial starter feeds have yet to be formulated for this species and among challenges in larval rearing are specific dietary fatty acid (FA) requirements during early ontogenetic development. Thus, dietary $n-3$ long-chain PUFA (LC-PUFA), such as EPA $(20: 5 n-3)$ and DHA $(22: 6 n-3)$, play critical roles in performance, neurological development and stress resilience of pikeperch larvae and fry; dietary DHA deficiency provokes shock syndromes and large mortalities ${ }^{(2-4)}$. Although other percid fishes, such as the close relative walleye (Sander vitreus), seem to have a comparative lower LC-PUFA requirement ${ }^{(5)}$ and Eurasian perch larvae (Perca fluviatilis) possess some capability to elongate and desaturate 18 -C $n-3$ PUFA to EPA and $\mathrm{DHA}^{(6)}$, recent research has indicated no such ability in pikeperch larvae and the necessity of a dietary supplementation of DHA. Hence, recent in vivo (1-C14) FA incubation studies in pikeperch larvae with the use of labelled $18: 3 n-3$ and EPA concluded that most of the $n-3$ elongation/desaturation products are consistent with the elongation of very long-chain FA, directly producing, respectively, $20: 3 n-3$ from $18: 3 n-3$ and $22: 5 n-3$ and $24: 5 n-3$ from EPA (R Covadonga, unpublished results). An observed $\Delta 6$ desaturase enzyme activity was also consistent with a significant production of $18: 4 n-3$ from $18: 3 n-3$; however, no further or any desaturation activity over EPA was evident, precluding the expression of $\Delta 5$ or even $\Delta 4$ desaturases in the larvae.

Abbreviations: DPH, days post-hatch; ER, endoplasmic reticulum; FA, fatty acids; Grp94, glucose-regulated 94; LC-PUFA, long-chain PUFA; PC, phosphatidylcholine; PDI, protein disulphide-isomerase; PI, phosphatidylinositol; PL, phospholipids; SBL, soyabean lecithin; SCP2, sterol carrier protein 2.

* Corresponding author: I. Lund, email il@aqua.dtu.dk

$\dagger$ These authors contributed equally to this work. 
The essentiality of phosphoglycerides (phospholipids (PL)) has been demonstrated since decades, exerting beneficial effects on growth, survival, stress resistance, enzymatic activity and performance of fish larvae or fry in a variety of marine and freshwater species ${ }^{(7-17)}$. Also in pikeperch, an increase in dietary PL improves growth and intestinal brush border membrane enzymatic activity, modulating expression of selected genes in liver ${ }^{(2,18)}$. The optimal dietary PL levels for this species has been suggested to be at least $9.5 \% \mathrm{DW}^{(2)}$, which is in the range of those reported in experimental trials for other freshwater and marine carnivorous species $(5-12 \%$ of dietary lipids $)^{(12,16,19)}$. Dietary inclusion of PL is typically in the form of soyabean lecithin $(\mathrm{SBL})^{(20,21)}$, but marine lecithins ${ }^{(22)}$ and, occasionally, egg yolk have also been used ${ }^{(23)}$. Consequently, the content and proportion of lipid classes and LC-PUFA may $\operatorname{vary}^{(16,24,25)}$ and affect the optimal inclusion in the diet for a given species ${ }^{(19,23,26,27)}$. SBL contains typically $65-75 \% \mathrm{PL}^{(28)}$, with about $20-25 \%$ each of the major phosphoglycerides: phosphatidylcholine (PC), phoshatidylethanolamine and phosphatidylinositol (PI). These are formed by L-glycerol with two FA esterified on positions 1 and 2, the second one typically with an unsaturated $\mathrm{FA}^{(16)}$. SBL contains no LC-PUFA but up to $50-55 \%$ of $18: 2 n-6$, and $4 \%$ of $18: 3 n-3$, together with $8-11 \%$ each of $16: 0,16: 1$ and $18: 1$, depending on the commercial product ${ }^{(29)}$

Despite a general consensus about the positive influence of either dietary $n$-3 LC-PUFA or PL during pikeperch larval ontogeny, the optimal supplemented levels and the combined effects of dietary PL and $n-3$ LC-PUFA during exogenous feeding are still controversial. Thus, growth improvement of pikeperch larvae has been related to the positive effect of dietary levels of PL independently of LC-PUFA levels ${ }^{(2,30)}$. This observation is in agreement with studies on larvae of the freshwater carp (Cyprinus carpio) and the amphidromous ayu (Plecoglossus altivelis) where SBL, despite lacking $n$-3 LC-PUFA, were as effective or even more effective than marine lecithins rich in $n$-3 LC-PUFA $^{(10,31)}$. In other studies, conducted with marine fish larvae, PL were superior to neutral lipids (NL) as a source of $\mathrm{EFA}^{(24)}$, and fish larvae reared on PL rich in $n-3$ LC-PUFA showed further enhanced growth, digestion and absorption, as well as an increased lipid transport and uptake into larval membranes ${ }^{(11,27,32)}$. The provision of $n$-3 LC-PUFA, as preformed intact PL (i.e. wild live preys such as copepods, marine lecithin and so on) or as NL or TAG (i.e. enriched cultured live preys such as rotifers, microdiets and so on), is probably a plausible explanation for the higher efficiency of the former in sustaining growth, survival and skeletal and ontogenetic development ${ }^{(19,32-37)}$. Ingested LC-PUFA are hydrolysed and emulsified in bile salts and passively transported over the enterocytes as monoacylglycerol (MAG) or free fatty acid and re-esterified or re-acylated to TAG or PL mainly on the $s n-2$ position. Although PL can be effectively synthesised by the enterocyte mainly by the glycerol-3-phosphate pathway, as well as by the MAG pathway, the efficiency of these pathways can be markedly impaired by dietary lipids ${ }^{(38)}$. Moreover, fish larvae have a poor development of enterocytes, and this may further reduce the ability to synthesise PL de novo ${ }^{(39)}$ and a low PL:TAG ratio is found to accumulate lipid droplets in the enterocytes ${ }^{(37)}$ by inhibiting the assembly of lipoprotein particles (chylomicrons and VLDL) or transport mechanisms out of the entero cytes and consequently cause TAG to accumulate in the intestinal epithelium ${ }^{(20,36,40)}$.

In the present study, we hypothesise that an increase in dietary PL in the presence of supplemented DHA (as TAG) may increase both the de novo PL synthesis and the incorporation of LC-PUFA (especially DHA) into the tissue molecules of both TAG and PL for optimal development and performance of pikeperch larvae during early larval development. Thus, the main objective was to determine optimal levels of SBL-derived PL in formulated extruded starter feeds and the additional effects of $n-3$ LC-PUFA TAG on performance and development of larval pikeperch. As an increased dietary PL may reduce bone malformations ${ }^{(27,31,41)}$ and liver proteomic studies can help to understand fish metabolism responses to dietary changes ${ }^{(42,43)}$, to better understand the physiological mechanisms implied in the effect of PL and $n-3$ LC-PUFA on larval performance, studies on hepatic proteomics, expression of lipid metabolism related genes, digestive enzymes activity and skeleton morphogenesis were also conducted.

\section{Methods}

\section{Experimental conditions}

Fertilised eggs of pikeperch were obtained from Aquapri Innovation, Egtved, Denmark and transferred in oxygenated plastic bags to DTU Aqua at the North Sea Research Centre, Denmark. Eggs were incubated until hatching in upflow McDonald type incubators with a flow-through system. Freshwater heated at $17.5^{\circ} \mathrm{C}$ from a temperature-controlled $10 \mathrm{~m}^{3}$ reservoir was constantly supplied. Hatched larvae were distributed into two $0.5 \mathrm{~m}^{3}$ fibreglass tanks and kept until $10 \mathrm{~d}$ post-hatch (DPH) at 19.5$20 \cdot 3^{\circ} \mathrm{C}$ and constant low-intensity light. From 3 to $10 \mathrm{DPH}$, larvae were fed newly hatched non-enriched Artemia nauplii (strain MC460; INVE, kept at $5^{\circ} \mathrm{C}$ after hatching) for $2 \times 8 \mathrm{~h}$ through a peristaltic pump (longer pumps, BT300-2J; Langer Instruments Corp.) to make sure that live Artemia nauplii were always present ad libitum (i.e. 1-3 individuals $/ \mathrm{ml}$ ) in the tanks. At $10 \mathrm{DPH}$, all larvae were mixed and moved to another temperature-controlled freshwater flow-through larval system consisting of eighteen conical tanks of 46 litre. Pikeperch larvae were manually distributed into these tanks at a density of seventeen larvae per litre and fed one of the six experimental dry diets until $30 \mathrm{DPH}$ under a water temperature of $20-20 \cdot 5^{\circ} \mathrm{C}$ and at dimmed light (30-40 lux at water surface) provided by electrical LED bulbs. Daily, the flow rate was adjusted at 15 litres/h per tank, and oxygen (7.8 (SD $0.4) \mathrm{mg} / \mathrm{l})$ and temperature $\left(20 \cdot 2(\mathrm{SD} 0 \cdot 1)^{\circ} \mathrm{C}\right)$ were monitored by a hand-held oxymeter (OxyGuard).

In total, six isonitrogenous and isoenergetic diets (Table 1) were formulated to contain three PL levels (PL1, PL2 and PL3), adding 3, 10 and 19\% SBL, and these same PL levels combined with increased DHA levels (PL1H1, PL2H2 and PL3H3) adding 0.55, 2 and 3.4\% Algatrium DHA70. Supplementation with SBL replaced olive oil in the diets. Olive oil with a high oleic acid content was used (>81\% wet weight) and with a limited $n-6$ and $n-3$ PUFA content. Experimental diets were manufactured by SPAROS. All powder ingredients were initially mixed and 
Table 1. Feed formulation and proximate analysis of the six experimental diets

\begin{tabular}{|c|c|c|c|c|c|c|}
\hline & PL1 & PL2 & PL3 & PL1H1 & PL2H2 & PL3H3 \\
\hline \multicolumn{7}{|l|}{ Diet ingredients (\%) } \\
\hline MicroNorse fishmeal ${ }^{\star}$ & 45 & 45 & 45 & 45 & 45 & 45 \\
\hline CPSP 90† & 7 & 7 & 7 & 7 & 7 & 7 \\
\hline Squid mealł & 13 & 13 & 13 & 13 & 13 & 13 \\
\hline Fish gelatin§ & 1 & 1 & 1 & 1 & 1 & 1 \\
\hline Wheat glutenll & 4.4 & 4.4 & 4.4 & 4.4 & 4.4 & 4.4 \\
\hline Wheat mealq & $6 \cdot 1$ & 5.9 & 5.6 & $6 \cdot 1$ & 5.9 & 5.6 \\
\hline Algatrium DHA70** & 0.0 & 0.0 & 0.0 & 0.55 & $2 \cdot 0$ & 3.4 \\
\hline Olive oilt† & 18.9 & $12 \cdot 1$ & 3.4 & $18 \cdot 35$ & $10 \cdot 1$ & 0.0 \\
\hline Vitamin and mineral premix PV01㧊 & 1.0 & 1.0 & $1 \cdot 0$ & 1.0 & 1.0 & 1.0 \\
\hline Soyabean lecithin powder§§ & 3.0 & $10 \cdot 0$ & $19 \cdot 0$ & 3.0 & $10 \cdot 0$ & $19 \cdot 0$ \\
\hline Binder (guar gum)||II & 0.2 & 0.2 & 0.2 & 0.2 & 0.2 & 0.2 \\
\hline Antioxidant powder (Paramega) $|\uparrow|$ & 0.2 & 0.2 & 0.2 & 0.2 & 0.2 & 0.2 \\
\hline Antioxidant liquid (Naturox) ( $^{\star \star \star}$ & 0.2 & 0.2 & 0.2 & 0.2 & 0.2 & 0.2 \\
\hline \multicolumn{7}{|l|}{ Analysed composition (\% wet weight) } \\
\hline Crude protein & $54 \cdot 1$ & 54.7 & $55 \cdot 6$ & $54 \cdot 1$ & $55 \cdot 8$ & $55 \cdot 3$ \\
\hline Crude lipid & $26 \cdot 8$ & $25 \cdot 9$ & 24.6 & $26 \cdot 6$ & $25 \cdot 6$ & $24 \cdot 8$ \\
\hline EPA (\% DM TFAt††) & 0.164 & 0.097 & 0.08 & 0.30 & 0.174 & 0.169 \\
\hline DHA (\% DM TFA) & 0.39 & 0.228 & 0.174 & 0.977 & 0.815 & 1.004 \\
\hline NFE + fibre (substracted) & $3 \cdot 0$ & 3.0 & $2 \cdot 8$ & $2 \cdot 8$ & $3 \cdot 1$ & 3.2 \\
\hline DM & 93.0 & 93.0 & $93 \cdot 1$ & 93.6 & $92 \cdot 8$ & 93.5 \\
\hline Ash & $9 \cdot 1$ & 9.4 & $10 \cdot 0$ & 9.0 & $9 \cdot 3$ & $10 \cdot 2$ \\
\hline $\mathrm{P}$ & 1.30 & 1.27 & 1.31 & 1.28 & 1.29 & 1.30 \\
\hline $\mathrm{Ca}$ & 1.84 & 1.85 & 1.85 & 1.83 & 1.84 & 1.85 \\
\hline \multicolumn{7}{|l|}{$\%$ protein } \\
\hline Lys & $4 \cdot 20$ & 4.22 & $4 \cdot 19$ & $4 \cdot 16$ & $4 \cdot 21$ & $4 \cdot 17$ \\
\hline Met + Cys & 1.90 & 1.93 & 1.90 & 1.91 & 1.87 & 1.89 \\
\hline Taurine & 0.52 & 0.50 & 0.51 & 0.52 & 0.52 & 0.51 \\
\hline \multicolumn{7}{|l|}{ (\% wet weight) } \\
\hline Phosphatidylcholine & 1.40 & $2 \cdot 61$ & 4.31 & 1.42 & 2.68 & 4.29 \\
\hline Phosphatidylethanolamine & 0.43 & 1.22 & $2 \cdot 20$ & 0.40 & 1.14 & 1.87 \\
\hline Phosphatidylinositol & 0.44 & 1.28 & 2.44 & 0.43 & 1.28 & 2.48 \\
\hline Total phospholipids & 3.73 & 8.19 & $14 \cdot 38$ & 3.70 & 8.32 & 14.51 \\
\hline
\end{tabular}

TFA, total fatty acids; NFE, N-free extract.

* MicroNorse Fish Meal: $71 \%$ crude protein and 9.8\% crude fat; Tromsø Fiskeindustri AS.

† Soluble fish-protein concentrate (CPSP 90): $84 \%$ crude protein and $12 \%$ fat; Sopropêche.

$\ddagger$ Squid meal: Super prime squid meal: $80 \%$ crude protein and $3.5 \%$ crude fat; Sopropêche.

§ Fish gelatin: $88 \%$ crude protein, $0.1 \%$ crude fat; LAPI Gelatine SPA.

II Wheat gluten: VITAL $83.7 \%$ crude protein and $1.4 \%$ crude fat; Roquette Frères.

II Wheat meal: $11.7 \%$ crude protein and $1.6 \%$ crude fat; Casa Lanchinha.

${ }^{\star \star}$ Algatrium DHA70: Brudy Technologies.

t† Olive oil: Henry Lamotte Oils $\mathrm{GmbH}$.

‡† PVO40.01 premix for marine fish (Premix Lda); vitamins (per kg diet): $100 \mathrm{mg}$ DL-a tocopherol acetate, $25 \mathrm{mg}$ sodium menadione bisulphate, $20000 \mathrm{IU}$ retinyl acetate, $2000 \mathrm{IU}$ DL-cholecalciferol, $30 \mathrm{mg}$ thiamin, $30 \mathrm{mg}$ riboflavin, $20 \mathrm{mg}$ pyridoxine, $0.1 \mathrm{mg} \mathrm{B} \mathrm{B}_{12}, 200 \mathrm{mg}$ nicotinic acid, $15 \mathrm{mg}$ folic acid, $1000 \mathrm{mg}$ ascorbic acid, $500 \mathrm{mg}$ inositol, $3 \mathrm{mg}$ biotin, $100 \mathrm{mg}$ calcium panthotenate, $1000 \mathrm{mg}$ choline chloride and $500 \mathrm{mg}$ betaine; minerals (per $\mathrm{kg}$ diet): $2.5 \mathrm{mg}$ cobalt sulphate, $1.1 \mathrm{mg}$ copper sulphate, $0.2 \mathrm{~g}$ ferric citrate, $5 \mathrm{mg}$ potassium iodide, $15 \mathrm{mg}$ manganese sulphate, $0.2 \mathrm{mg}$ sodium selenite, $40 \mathrm{mg}$ zinc sulphate, $0.6 \mathrm{~g}$ magnesium hydroxide, $1.1 \mathrm{~g}$ potassium chloride, $0.5 \mathrm{~g}$ sodium chloride and $4 \mathrm{~g}$ calcium carbonate.

§§ Soya lecithin powder: Lecico P700IPM; LECICO GmbH

IIII Binder (guar gum): HV109; SEAH International.

IT Antioxidant powder: Paramega PX; KEMIN EUROPE NV.

*** Antioxidant liquid: NATUROX; KEMIN EUROPE NV.

††† TFA, thirty-four analysed.

ground in a micropulveriser hammer mill (SH1; HosokawaAlpine). Subsequently, the oils were added, diets humidified with $25 \%$ deionised water and agglomerated by a low-shear and temperature-controlled extrusion process (P55; Italplast). The resulting pellets $(0.8 \mathrm{~mm})$ were dried in a convection oven for $3 \mathrm{~h}$ at $40^{\circ} \mathrm{C}$ (OP 750-UF; LTE Scientifics), crumbled (103; Neuero Farm) and mechanically sieved (Eco-Separator; RussellFinex) to particle size ranges (400-600 and $800 \mu \mathrm{m}$ ).

From 10 to $17 \mathrm{DPH}$, triplicate groups of larvae were co-fed one of the six experimental dry feeds together with newly nonenriched Artemia nauplii (INVE) from 08.00 to 22.00 hours. During this period, Artemia feeding was daily postponed by $1 \mathrm{~h}$. From 10 to $17 \mathrm{DPH}$, larvae were fed a diet with a pellet size of $400-600 \mu \mathrm{m}$ (initially further ground in a mortar to 200$250 \mu \mathrm{m}$ ), which was gradually increased to $600-800 \mu \mathrm{m}$ during the 2 nd week. A mixture of these two size ranges was applied for the remaining experiment until 30 DPH. Dry feed was daily administered by eighteen programmable automatic feeders (screw feeders; made by DTU Aqua), which allowed very small quantities to be fed at short specific time intervals (approximately $15 \mathrm{~min}$ ) during the entire feeding period. Dry feeds were administered at $25 \%$ of expected larval biomass in the 1 st weeks and 10-15\% during the last week. Larvae were not fed $12 \mathrm{~h}$ before sampling for analytical purpose to ensure an empty gut. Tank bottom was daily vacuum-cleaned to remove uneaten feed and to count dead larvae. 


\section{Larval sampling}

A representative number of larvae $(2 \times 100)$ were sampled at hatching (0 DPH) and $10 \mathrm{DPH}$ for FA analysis and fifty larvae sampled for initial weight measurement. At $30 \mathrm{DPH}, 2 \times 10$ larvae per replicate tank were sampled for PL and FA analysis. In all, ten larvae per tank were sampled for analysis of digestive enzymes at $30 \mathrm{DPH}$. In addition, $2 \times 10$ larvae per replicate were sampled for proteomics at $30 \mathrm{DPH}$. All larvae were killed by an overdose of benzocaine and immediately frozen and kept at $-80^{\circ} \mathrm{C}$ until analysis. At $30 \mathrm{DPH}$, an additional ten larvae per tank were sampled for larval organ and skeleton development for specific staining of bone and cartilage and stored in $10 \%$ phosphate-buffered formaldehyde. To quantify the gene expression involved in skeletal development, ten larvae per replicate were sampled and stored in RNA-later overnight and frozen at $-80^{\circ} \mathrm{C}$ until analysis.

\section{Larval survival and growth}

Daily mortality was assessed by the number of registered dead larvae, whereas the total number of alive larvae manually counted at the end of the trial was considered as the final survival in each tank. Growth was determined by individually weighing 100 randomly sampled larvae at $10 \mathrm{DPH}$ and thirtyfive larvae per replicate tank at $30 \mathrm{DPH}$. Each anaesthetised larva was wiped to remove excess water (medical care tissue cloth) and weighed to the nearest $0.01 \mathrm{mg}$ on a Mettler Toledo AT200. Mean larval weight at $10 \mathrm{DPH}$ was 1.95 (sD 0.31) mg wet weight and 0.56 (sD 0.09) mg DM. Specific daily growth rate (SGR) (\% per d) was calculated according to the following equation: SGR = (In (final average body weight of sampled larvae) - In (initial average body weight of sampled larvae) $) \times 100 /$ feeding days.

\section{Biochemical analysis}

Representative samples of the six diets were homogenised using a Krups Speedy Pro homogenizer 244 and analysed for DM and ash (NMKL, 1991), crude protein 245 (ISO 2005; crude protein; Kjeldahl $\mathrm{N} \times 6.25)$ and crude lipid ${ }^{(44)}$. N-free extract (NFE) was calculated as DM minus the sum of crude protein, crude lipid and ash. The proximate composition of the diets was similar in terms of protein, lipid, NFE and ash content and with almost identical values of the essential amino acids, lysine, methionine and cysteine and the sulphur-containing non-protein amino acid taurine (Table 1).

The FA composition in diets (Table 2) and larvae (Table 3) was determined by lipid extraction with a chloroform-methanol mixture $^{(45)}$ and either sonicated in an ultrasound cleaner, model Branson, 2510, or homogenised (larger larvae) by a tissuetearor probe with a diameter of $4.5 \mathrm{~mm}$ (Biospec Products, Inc.). Trans-esterification of the lipids was performed by acetyl chloride in methanol at $95^{\circ} \mathrm{C}$. The FA methyl esters were

Table 2. Analysed total fatty acids (TFA) content (mg/g DM) and fatty acid (FA) composition (\% of TFA) of the six experimental diets* (Mean values and standard deviations, $n$ 2)

\begin{tabular}{|c|c|c|c|c|c|c|c|c|c|c|c|c|}
\hline \multirow[t]{2}{*}{ Diets... } & \multicolumn{2}{|c|}{ PL1 } & \multicolumn{2}{|c|}{ PL2 } & \multicolumn{2}{|c|}{ PL3 } & \multicolumn{2}{|c|}{ PL1H1 } & \multicolumn{2}{|c|}{ PL2H2 } & \multicolumn{2}{|c|}{ PL3H3 } \\
\hline & Mean & $\mathrm{SD}$ & Mean & SD & Mean & $\mathrm{SD}$ & Mean & SD & Mean & $\mathrm{SD}$ & Mean & $S D$ \\
\hline $\begin{array}{l}\text { TFA } \\
\text { FA }\end{array}$ & $109 \cdot 4$ & $5 \cdot 7$ & $54 \cdot 3$ & $26 \cdot 0$ & $34 \cdot 1$ & $8 \cdot 2$ & $187 \cdot 8$ & $30 \cdot 6$ & $69 \cdot 7$ & 9.6 & 46.9 & 6.9 \\
\hline $14: 0$ & 0.7 & 0.0 & 0.8 & 0.0 & 1.0 & 0.0 & 0.7 & 0.0 & 0.79 & 0.0 & 1.0 & 0.0 \\
\hline $16: 0$ & $13 \cdot 0$ & 0.2 & $14 \cdot 6$ & 0.1 & $17 \cdot 8$ & 0.1 & $12 \cdot 9$ & 0.2 & $13 \cdot 8$ & 0.0 & $15 \cdot 2$ & 0.1 \\
\hline $18: 0$ & $2 \cdot 6$ & 0.0 & $2 \cdot 7$ & 0.0 & $2 \cdot 9$ & 0.0 & 2.5 & 0.0 & $2 \cdot 4$ & 0.0 & $2 \cdot 3$ & 0.0 \\
\hline $20: 0$ & 0.3 & 0.0 & 0.2 & 0.0 & 0.2 & 0.0 & 0.3 & 0.0 & 0.22 & 0.0 & $0 \cdot 10$ & 0.0 \\
\hline $22: 0$ & 0.1 & 0.0 & 0.2 & 0.0 & 0.3 & 0.0 & 0.1 & 0.0 & 0.1 & 0.0 & 0.2 & 0.0 \\
\hline $24: 0$ & 0.1 & 0.0 & 0.1 & 0.0 & 0.2 & 0.0 & 0.1 & 0.0 & 0.1 & 0.0 & 0.1 & 0.0 \\
\hline Total SFA & $17 \cdot 0$ & 0.3 & 18.9 & 0.1 & 22.6 & 0.1 & $16 \cdot 8$ & 0.1 & $17 \cdot 7$ & 0.0 & $19 \cdot 3$ & 0.1 \\
\hline $16: 1 n-7$ & 1.5 & 0.0 & 1.4 & 0.0 & 1.4 & 0.0 & 1.5 & 0.0 & 1.4 & 0.0 & $1 \cdot 3$ & 0.0 \\
\hline $18: 1 n-9$ & $62 \cdot 1$ & 0.2 & 50.0 & 0.1 & 27.0 & 0.0 & $60 \cdot 1$ & 0.4 & $42 \cdot 6$ & 0.1 & 12.4 & 0.0 \\
\hline $20: 1 n-9$ & 1.6 & 0.0 & 1.7 & 0.0 & 2.0 & 0.0 & 1.5 & 0.0 & 1.7 & 0.0 & 1.9 & 0.0 \\
\hline $22: 1 n-9$ & 0.2 & 0.0 & 0.2 & 0.0 & 0.2 & 0.0 & 0.1 & 0.0 & 0.2 & 0.0 & 0.2 & 0.0 \\
\hline $24: 1 n-9$ & 0.9 & 0.0 & $1 \cdot 1$ & 0.0 & 1.3 & 0.0 & 1.3 & 0.1 & $2 \cdot 6$ & 0.0 & 4.5 & 0.0 \\
\hline Total MUFA & $66 \cdot 4$ & 0.2 & 54.5 & 0.1 & $32 \cdot 0$ & 0.0 & 65.5 & 0.4 & 48.5 & 0.0 & $20 \cdot 4$ & 0.0 \\
\hline $18: 2 n-6$ & $10 \cdot 1$ & 0.0 & 18.6 & 0.1 & 34.5 & 0.0 & 9.6 & 0.2 & 17.5 & 0.1 & 31.9 & 0.1 \\
\hline $18: 3 n-6$ & 0.0 & 0.0 & 0.0 & 0.0 & 0.0 & 0.0 & 0.0 & 0.0 & 0.0 & 0.0 & 0.0 & 0.0 \\
\hline $20: 2 n-6$ & 0.1 & 0.0 & 0.1 & 0.0 & 0.1 & 0.0 & 0.1 & 0.0 & 0.1 & 0.0 & 0.1 & 0.0 \\
\hline $20: 3 n-6$ & 0.0 & 0.0 & 0.0 & 0.0 & 0.0 & 0.0 & 0.0 & 0.0 & 0.0 & 0.0 & 0.0 & 0.0 \\
\hline $20: 4 n-6$ & 0.2 & 0.0 & 0.2 & 0.0 & 0.2 & 0.0 & 0.2 & 0.0 & 0.2 & 0.0 & 0.3 & 0.0 \\
\hline Total $(n-6)$ & $10 \cdot 4$ & 0.0 & 18.9 & 0.1 & 34.9 & 0.0 & 9.9 & 0.2 & $17 \cdot 9$ & 0.0 & 32.4 & 0.1 \\
\hline $18: 3 n-3$ & $1 \cdot 1$ & 0.0 & 1.7 & 0.0 & 3.1 & 0.0 & 1.0 & 0.0 & $1 \cdot 6$ & 0.0 & $2 \cdot 8$ & 0.0 \\
\hline $20: 3 n-3$ & 0.0 & 0.0 & 0.0 & 0.0 & 0.1 & 0.0 & 0.0 & 0.0 & 0.0 & 0.0 & 0.1 & 0.0 \\
\hline $20: 5 n-3$ & 1.5 & 0.0 & 1.8 & 0.0 & $2 \cdot 3$ & 0.0 & 1.6 & 0.1 & $2 \cdot 5$ & 0.1 & 3.6 & 0.0 \\
\hline $22: 6 n-3$ & 3.6 & 0.1 & 4.2 & 0.0 & 5.1 & 0.0 & $5 \cdot 2$ & 0.2 & 11.7 & 0.0 & 21.4 & 0.2 \\
\hline Total $(n-3)$ & $6 \cdot 2$ & 0.1 & $7 \cdot 7$ & 0.0 & 10.5 & 0.0 & 7.9 & 0.3 & $15 \cdot 9$ & 0.0 & 27.9 & 0.1 \\
\hline DHA/EPA & 2.4 & 0.1 & $2 \cdot 3$ & 0.0 & $2 \cdot 2$ & 0.1 & $3 \cdot 3$ & 0.0 & 4.8 & 0.2 & 5.9 & 0.1 \\
\hline$n-3 / n-6$ & 0.6 & 0.0 & 0.4 & 0.0 & 0.3 & 0.0 & 0.8 & 0.0 & 0.9 & 0.0 & 0.9 & 0.0 \\
\hline
\end{tabular}

* PL1, PL2 and PL3 (soyabean lecithin (SBL): 3, 10 and 19\%); PL1H1, PL2H2 and PL1H3 (SBL: 3, 10 and 19\%) + Algatrium DHA 70: 0.55, 2.05 and 3.4\%. 
Table 3. Analysed total fatty acids (TFA) content and fatty acid (FA) composition (\% of TFA) of total lipids in pikeperch larvae at 0 and $10 \mathrm{~d}$ post-hatch (DPH), as well as in $30 \mathrm{DPH}\left(\mathrm{mg} / \mathrm{g}\right.$, wet weight), after $20 \mathrm{~d}$ of feeding experimental diets ${ }^{\star}$

(Mean values and standard deviations, $n 3$ )

\begin{tabular}{|c|c|c|c|c|c|c|c|c|c|c|c|c|c|c|c|c|}
\hline \multirow{3}{*}{$\begin{array}{l}\text { Larval age... } \\
\text { Diets... }\end{array}$} & \multirow{2}{*}{\multicolumn{2}{|c|}{ DPH 0}} & \multirow{2}{*}{\multicolumn{2}{|c|}{ DPH 10}} & \multirow{2}{*}{\multicolumn{2}{|c|}{$\frac{\text { DPH } 30}{\text { PL1 }}$}} & \multirow{2}{*}{\multicolumn{2}{|c|}{ PL2 }} & \multirow{2}{*}{\multicolumn{2}{|c|}{ PL3 }} & \multirow{2}{*}{\multicolumn{2}{|c|}{ PL1H1 }} & \multirow{2}{*}{\multicolumn{2}{|c|}{ PL2H2 }} & \multirow{2}{*}{\multicolumn{2}{|c|}{ PL3H3 }} \\
\hline & & & & & & & & & & & & & & & & \\
\hline & Mean & SD & Mean & SD & Mean & SD & Mean & SD & Mean & SD & Mean & SD & Mean & SD & Mean & SD \\
\hline \multicolumn{16}{|l|}{ FA $(\%$ TFA $)$} & $15 \cdot 6$ \\
\hline $14: 0$ & 0.9 & 0.0 & 0.5 & 0.0 & 0.4 & 0.0 & 0.3 & 0.2 & 0.6 & 0.1 & 0.4 & 0.0 & 0.5 & 0.1 & 0.6 & 0.1 \\
\hline $16: 0$ & 11.9 & 0.9 & 13.5 & 0.6 & $13 \cdot 5^{\mathrm{b}}$ & 0.1 & $14 \cdot 5^{\mathrm{b}}$ & 1.5 & $18 \cdot 3^{a}$ & 0.4 & $13 \cdot 1^{\mathrm{b}}$ & 0.3 & $13 \cdot 9^{b}$ & 0.5 & $14 \cdot 8^{\mathrm{b}}$ & 0.6 \\
\hline $18: 0$ & 3.3 & 0.2 & $7 \cdot 2$ & 0.2 & $4 \cdot 4^{\mathrm{C}}$ & 0.0 & $4 \cdot 2^{b, c}$ & 0.1 & $4.5^{\mathrm{c}}$ & 0.3 & $3.7^{b}$ & 0.2 & $3 \cdot 0^{\mathrm{a}}$ & 0.1 & $3.0^{\mathrm{a}}$ & 0.2 \\
\hline $20: 0$ & 0.1 & 0.0 & 0.2 & 0.0 & $0.1^{\mathrm{b}}$ & 0.0 & $0 \cdot 1^{\mathrm{a}, \mathrm{b}}$ & 0.0 & $0.1^{\mathrm{a}}$ & 0.0 & $0 \cdot 1^{b}$ & 0.0 & $0.1^{\mathrm{a}}$ & 0.0 & $0.1^{\mathrm{a}}$ & 0.0 \\
\hline $22: 0$ & 0.2 & 0.1 & 0.4 & 0.0 & $0.1^{\mathrm{b}}$ & 0.0 & $0.1^{\mathrm{b}}$ & 0.0 & $0.1^{a, b}$ & 0.0 & $0.1^{b}$ & 0.0 & $0.0^{\mathrm{a}}$ & 0.0 & $0.0^{\mathrm{a}}$ & 0.0 \\
\hline $24: 0$ & 0.0 & 0.0 & $0 \cdot 1$ & 0.0 & 0.1 & 0.0 & 0.0 & 0.0 & 0.1 & 0.0 & 0.0 & 0.0 & 0.0 & 0.0 & 0.0 & 0.0 \\
\hline Total SFA & $16 \cdot 9$ & 0.9 & $22 \cdot 8$ & 1.0 & $19 \cdot 0$ & 0.1 & $19 \cdot 6$ & 1.6 & $24 \cdot 1$ & 0.3 & $17 \cdot 8$ & 0.4 & $17 \cdot 9$ & 0.6 & $18 \cdot 8$ & 0.8 \\
\hline $16: 1 n-7$ & $6 \cdot 8$ & 0.3 & $2 \cdot 3$ & 0.2 & 1.3 & 0.0 & 1.2 & 0.2 & 1.2 & 0.1 & 1.3 & 0.1 & 1.4 & 0.1 & $1 \cdot 1$ & 0.1 \\
\hline $18: 1 n-9$ & 12.0 & 0.4 & 22.5 & 0.1 & $50 \cdot 5^{\mathrm{e}}$ & 0.5 & $43 \cdot 8^{d}$ & 0.8 & $24.7^{\mathrm{b}}$ & 0.8 & $50 \cdot 3^{e}$ & 1.8 & $37 \cdot 4^{c}$ & $1 \cdot 1$ & $12 \cdot 8^{a}$ & 1.0 \\
\hline $20: 1 n-9$ & $1 \cdot 1$ & 0.1 & 0.5 & 0.0 & $1.1^{\mathrm{c}}$ & 0.0 & $1 \cdot 2^{\mathrm{c}}$ & 0.0 & $1.0^{\mathrm{b}}$ & 0.0 & $1 \cdot 1^{\mathrm{c}}$ & 0.0 & $1.0^{\mathrm{b}}$ & 0.0 & $0.8^{a}$ & 0.0 \\
\hline $22: 1 n-9$ & 0.0 & 0.0 & $0 \cdot 1$ & 0.0 & 0.1 & 0.0 & 0.1 & 0.0 & 0.1 & 0.0 & $0 \cdot 1$ & 0.0 & $0 \cdot 1$ & 0.0 & 0.1 & 0.0 \\
\hline $24: 1 n-9$ & $7 \cdot 3$ & 0.7 & 1.9 & 0.1 & $2 \cdot 3^{a, b}$ & 0.1 & $2 \cdot 0^{\mathrm{a}}$ & 0.1 & $2 \cdot 4^{\mathrm{b}}$ & 0.1 & $2 \cdot 5^{\mathrm{b}}$ & 0.2 & $3 \cdot 1^{c}$ & 0.2 & $5 \cdot 2^{d}$ & 0.2 \\
\hline Total MUFA & $27 \cdot 3$ & 0.2 & $28 \cdot 1$ & 0.1 & $55 \cdot 6^{\mathrm{e}}$ & 0.4 & $48 \cdot 4^{\mathrm{d}}$ & 0.6 & $29 \cdot 7^{b}$ & 0.4 & $55 \cdot 7^{e}$ & 1.7 & $43 \cdot 2^{c}$ & 1.0 & $20 \cdot 2^{a}$ & 0.9 \\
\hline $18: 2 n-6$ & 8.3 & $0 . \overline{6}$ & $7 \cdot 4$ & 0.2 & $11.0^{\mathrm{a}}$ & 0.1 & $18 \cdot 7^{\mathrm{b}}$ & 0.2 & $29 \cdot 1^{c}$ & 0.4 & $10 \cdot 7^{a}$ & 0.0 & $19 \cdot 2^{b}$ & 0.1 & $28 \cdot 5^{\mathrm{C}}$ & 0.5 \\
\hline $18: 3 n-6$ & 0.1 & 0.0 & 0.5 & 0.0 & $0 \cdot 2^{\mathrm{a}, \mathrm{b}}$ & 0.0 & $0.3^{b, c}$ & 0.0 & $0.6^{\mathrm{d}}$ & 0.0 & $0.2^{\mathrm{a}}$ & 0.0 & $0.3^{c}$ & 0.0 & $0.3^{c}$ & 0.0 \\
\hline $20: 2 n-6$ & 0.0 & 0.0 & 0.2 & 0.0 & $0.1^{\mathrm{a}}$ & 0.0 & $0.1^{a}$ & 0.1 & $0.3^{\mathrm{b}}$ & 0.0 & $0.1^{a}$ & 0.0 & $0.2^{\mathrm{a}}$ & 0.0 & $0.2^{a, b}$ & 0.0 \\
\hline $20: 3 n-6$ & 0.0 & 0.0 & 0.2 & 0.0 & $0.3^{b}$ & 0.0 & $0.3^{\mathrm{b}}$ & 0.0 & $0.6^{\mathrm{d}}$ & 0.0 & $0.2^{c}$ & 0.0 & $0.2^{c}$ & 0.0 & $0.1^{a}$ & 0.0 \\
\hline $20: 4 n-6$ ARA & 1.2 & 0.0 & 0.9 & 0.0 & $0.5^{\mathrm{b}, \mathrm{c}}$ & 0.0 & $0.3^{a}$ & 0.1 & $0.4^{\mathrm{a}, \mathrm{b}}$ & 0.1 & $0.4^{\mathrm{b}}$ & 0.0 & $0 \cdot 4^{a, b}$ & 0.0 & $0.6^{\mathrm{c}}$ & 0.1 \\
\hline Total $(n-6)$ PUFA & $9 \cdot 7$ & 0.6 & 9.3 & 0.3 & $12 \cdot 1^{\mathrm{a}}$ & 0.1 & $19.6^{\mathrm{b}}$ & 0.1 & $31.0^{\mathrm{e}}$ & 0.4 & $11 \cdot 6^{\mathrm{a}}$ & 0.1 & $20 \cdot 2^{c}$ & 0.1 & $29 \cdot 7^{d}$ & 0.5 \\
\hline $18: 3 n-3$ & 1.1 & 0.0 & $27 \cdot 1$ & 0.3 & $1 \cdot 3^{a, b}$ & 0.1 & $1 \cdot 3^{\mathrm{a}, \mathrm{b}}$ & 0.0 & $1.9^{\mathrm{C}}$ & 0.1 & $1 \cdot 1^{\mathrm{a}}$ & 0.2 & $1.5^{\mathrm{b}}$ & 0.1 & $1.9^{c}$ & 0.2 \\
\hline $20: 3 n-3$ & 0.1 & 0.1 & 1.3 & 0.0 & $0.1^{\mathrm{c}}$ & 0.0 & $0.1^{\mathrm{a}}$ & 0.0 & $0.1^{\mathrm{b}}$ & 0.0 & $0 \cdot 1^{a, b, c}$ & 0.0 & $0 \cdot 1^{a, b}$ & 0.0 & $0 \cdot 1^{a, b}$ & 0.0 \\
\hline $20: 5 n-3$ EPA & $7 \cdot 9$ & 0.3 & $2 \cdot 8$ & 0.2 & $2 \cdot 5^{\mathrm{a}}$ & 0.1 & $2 \cdot 2^{\mathrm{a}}$ & 0.2 & $2 \cdot 6^{a}$ & 0.2 & $2 \cdot 5^{\mathrm{a}}$ & 0.2 & $2 \cdot 6^{a}$ & 0.3 & $3.9^{b}$ & 0.2 \\
\hline $22: 6 n-3 \mathrm{DHA}$ & 37.1 & 0.3 & 8.5 & 0.8 & $9 \cdot 4^{\mathrm{a}}$ & 0.3 & $8 \cdot 6^{\mathrm{a}}$ & 0.8 & $10 \cdot 6^{\mathrm{b}}$ & 0.4 & $11 \cdot 2^{\mathrm{b}}$ & 0.9 & $14 \cdot 6^{\mathrm{C}}$ & $1 \cdot 1$ & $25 \cdot 4^{d}$ & 0.8 \\
\hline Total $(n-3)$ PUFA & $46 \cdot 1$ & 0.5 & 39.7 & 0.7 & $13 \cdot 3^{a}$ & 0.3 & $12 \cdot 2^{\mathrm{a}}$ & 1.0 & $15 \cdot 3^{b}$ & 0.7 & $14 \cdot 8^{a, b}$ & 1.2 & $18 \cdot 7^{\mathrm{C}}$ & 1.4 & $31 \cdot 2^{d}$ & 0.8 \\
\hline DHA/EPA & 4.7 & 0.1 & 3.1 & 0.0 & $3.8^{\mathrm{a}}$ & 0.0 & $3 \cdot 9^{\mathrm{a}, \mathrm{b}}$ & 0.2 & $4 \cdot 2^{\mathrm{b}}$ & 0.0 & $4 \cdot 5^{\mathrm{c}}$ & 0.0 & $5 \cdot 7^{d}$ & 0.3 & $6 \cdot 6^{\mathrm{e}}$ & 0.2 \\
\hline$n-3 / n-6$ & 4.8 & 0.3 & 4.3 & 0.1 & $1 \cdot 1^{\mathrm{b}}$ & 0.0 & $0.6^{\mathrm{a}}$ & 0.1 & $0.5^{\mathrm{a}}$ & 0.0 & $1 \cdot 3^{\mathrm{C}}$ & 0.1 & $0.9^{b}$ & 0.1 & $1 \cdot 1^{\mathrm{b}}$ & 0.0 \\
\hline
\end{tabular}

ARA, arachidonic acid.

a,b,c,d,e Mean values (for larvae fed the experimental diets (30 DPH) within a row followed by unlike superscript letters were significantly different $(P<0.05)$.

${ }^{*}$ PL1, PL2 and PL3 (soyabean lecithin (SBL): 3, 10 and 19\%); PL1H1, PL2H2 and PL1H3 (SBL: 3, 10 and 19\%) + Algatrium DHA 70: 0.55, 2.05 and 3.4\%.

analysed by GC-MS. Peaks on a given chromatogram were identified by comparison with the retention time of a commercial mix of a known FAME standard, SUPELCO 18919 (4:024:0), from SIGMA. Peaks were quantified by means of the target response factor of the FA and 23:0 as internal standard. FA concentrations were calculated (version E.02.02.1431; ChemStation) on the basis of the quantified peaks of the standard series and the samples, as well of dry weight of prey and larvae, and expressed as ng/sample.

A total of thirty-four FA were analysed, with the twenty most relevant FA shown (Tables 2 and 3). Total FA (TFA) differed between the diets and decreased by substitution of olive oil with SBL. The main differences in dietary FA profiles (\% TFA) were related to oleic acid (18:1n-9), linoleic acid $(18: 2 n-6)$, $\alpha$-linolenic acid (18:3n-3), EPA, DHA and consequently total MUFA, $n-6$ PUFA and n-3 PUFA (Table 2), 18:2n-6 and $18: 3 n-3$ content increased by the increased supplementation of SBL, for which $18: 2 n-6$ is the dominant FA (approximately $55 \%$ TFA, data not shown) with the additional content of some 18: 3n-3 (3\% TFA). Diets PL1H1-PL3H3 contained significantly increased levels of EPA and DHA (as compared with diets PL1PL3) owing to the supplementation of Algatrium DHA 70.

Quantification of PL in diets and larvae was performed by Spectral Service AG, by use of ${ }^{31}$ P-NMR spectroscopy using an internal standard according to the method previously described $^{(46)}$. Preweighed homogeneous subsamples of feed or larvae (30 DPH) were used, and before analysis larvae for each replicate were freeze-dried for $24 \mathrm{~h}$ on an Adolf Kühner AG Beta 2-16. NMR analyses were carried out on a Bruker DRX 600 spectrometer (Bruker Biospin $\mathrm{GmBH}$ ), resonating at $600 \cdot 13 \mathrm{MHz}$ for ${ }^{1} \mathrm{H}$ and 150.90 for ${ }^{13} \mathrm{C}$, using a $5-\mathrm{mm}$ BBO probe at $297 \mathrm{~K}$. For the quantification of $\mathrm{PL}$ in the samples, a defined amount of the test substance and corresponding internal standard (exactly weighed) were dissolved in CDCL3, methanol and aqueous CS-EDTA solution $(0.2 \mathrm{~m}, \mathrm{pH} 7.5)$. After $30 \mathrm{~min}$ of shaking, the organic layer was separated by centrifugation and measured with ${ }^{31} \mathrm{P}-\mathrm{NMR}$. The integrated signals of the test substance and of the internal standard triphenylphosphate were used for calculation.

The dietary analytical content of the three main PL classes identified increased as expected by dietary incorporation of SBL (Table 1). Total PL content ranged from 3.7\% (\% of lipids) for PL1 and PL1H1 to approximately $14 \cdot 4-14.5 \%$ for diets PL3 and PL3H3.

\section{Digestive enzyme activity}

The heads and tails of pikeperch ( $S$. lucioperca) larvae were removed to isolate the digestive segment on a glass maintained 
on ice $\left(0^{\circ} \mathrm{C}\right)$, and the stomach region was separated with the intestinal segments. Pooled samples from each tank were homogenised in 10 volumes $(\mathrm{v} / \mathrm{w})$ of cold distilled water. Assay of the cytosolic peptidase, leucine-alanine peptidase (leu-ala), was performed according to the method of Nicholson \& $\mathrm{Kim}^{(47)}$ using leucine-alanine (Sigma-Aldrich) as substrate. Alkaline phosphatase (AP) and aminopeptidase $\mathrm{N}$, two enzymes of brush border membrane, were assayed according to Bessey et $a l .{ }^{(48)}$ and Maroux et al. ${ }^{(49)}$ using $p$-nitrophenyl phosphate (Sigma-Aldrich) and L-leucine $p$-nitroanalide (Sigma-Aldrich) as substrates, respectively. Pepsin was assayed by the method of Worthington $^{(50)}$ modified by Cuvier-Péres and Kestemont ${ }^{(51)}$. Trypsin and amylase activities were assayed according to Holm et $a l .{ }^{(52)}$ and Metais and Bieth ${ }^{(53)}$, respectively such as described by Gisbert et al. ${ }^{(54)}$. Protein was determined using the Bradford procedure $^{(55)}$. Enzyme activities are expressed as specific activities ( $\mathrm{mU} / \mathrm{mg}$ protein).

\section{Skeleton anomalies and related gene expression}

Skeleton analyses were conducted on fixed $30 \mathrm{DPH}$ pikeperch larvae. These were stained with alizarin red to evaluate the skeletal anomalies and vertebral mineralisation according to methods ${ }^{(56)}$ modified from previous studies ${ }^{(57)}$. Classification of skeletal anomalies was conducted according to Boglione et al. ${ }^{(58)}$. Anomalies were expressed as frequency of total severe anomalies and specific anomalies, such as cranial, dentary, branchiostegal, prehaemal and caudal vertebrae, within each dietary group. The effects of the different weaning diets on the axial skeleton mineralisation were evaluated considering the total number of completely mineralised vertebral bodies within a larval size class.

Total RNA from larvae samples (average weight per sample $60 \mathrm{mg}$ ) was extracted using the Rneasy Mini Kit (Qiagen). Total body tissue was homogenised using the Tissue Lyzer-II (Qiagen) with QIAzol lysis reagent (Qiagen). Samples were centrifuged with chloroform for phase separation (12000 g, $15 \mathrm{~min}$, $4^{\circ} \mathrm{C}$ ). The upper aqueous phase containing RNA was mixed with $75 \%$ ethanol and transferred into an RNeasy spin column where total RNA bonded to a membrane and contaminants were washed away by RW1 and RPE buffers (Qiagen). Purified RNA was eluted with $30 \mu$ of RNase-free water. The quality and quantity of RNA were analysed using the NanoDrop 1000 Spectrophotometer (Thermo Scientific) and by electrophoresis of total RNA in a $1 \%$ agarose gel. Synthesis of complementary DNA (cDNA) was conducted using the iScript cDNA Synthesis Kit (Bio-Rad) according to manufacturer's instructions in an iCycler thermal cycler (Bio-Rad). Primer efficiency was tested with serial dilutions of a cDNA pool (1, 1:5, $1: 10,1: 15,1: 20$ and 1:25). Product size of the real-time quantitative PCR amplification was checked by electrophoresis analyses using PB322 cut with HAEIII as a standard. Real-time quantitative PCR was performed in an iQ5 Multicolor real-time PCR detection system (Bio-Rad; Hercules) using RAG1 as the housekeeping gene in a final volume of $20 \mu \mathrm{l} /$ reaction well, and $100 \mathrm{ng}$ of total RNA reverse-transcribed to complementary cDNA. Each gene sample was analysed once per gene. The PCR conditions were as follows: $95^{\circ} \mathrm{C}$ for $3 \mathrm{~min} 30 \mathrm{~s}$ followed by forty cycles of $95^{\circ} \mathrm{C}$ for $15 \mathrm{~s}, 61^{\circ} \mathrm{C}$ for $30 \mathrm{~s}$ and $72^{\circ} \mathrm{C}$ for $30 \mathrm{~s}, 95^{\circ} \mathrm{C}$ for $1 \mathrm{~min}$ and a final denaturing step from 61 to $95^{\circ} \mathrm{C}$ for $10 \mathrm{~s}$. Data obtained were normalised and the Livak method $\left(2^{-\Delta \Delta C_{t}}\right)$ was used to determine relative mRNA expression levels. Pikeperch-specific gene primers were designed after searching the NCBI nucleotide database and using the Oligo 7 Primer Analysis software (Molecular Biology Insights). Within the oligo used, RAG1, ALP, Twist2, Mef2c and Sox9 oligonucleotide primers were designed by extracting fish mRNA sequences from NCBI, aligning with MEGA 7 software and identifying conserved domains, to which primers were designed using Primer3 (version 0.4.0) program. Target specificity was tested by sequencing the resulting amplicons and comparing with the NCBI sequence database using BLAST. Detailed information on primer sequences and accession numbers is presented in Table 4 .

\section{Proteomics}

Slightly thawed larvae (30 DPH) were dissected on a glass plate maintained at $0^{\circ} \mathrm{C}$. The liver was extracted and immediately frozen in liquid $\mathrm{N}_{2}$ and kept at $-80^{\circ} \mathrm{C}$ until analysis. In total, three independent biological replicates were used for each experimental condition. The soluble protein fractions were harvested by centrifugation at $12000 \boldsymbol{g}$ for $15 \mathrm{~min}$ at $4^{\circ} \mathrm{C}$. The $\mathrm{pH}$ of the protein extract was adjusted to 8.5 by addition of an appropriate volume of $50 \mathrm{mM} \mathrm{NaOH}$ and protein concentration was evaluated using a Pierce 660-nm protein assay kit as described by the manufacturer. Minimal labelling of samples (containing $25 \mu \mathrm{g}$ of solubilised proteins) was performed on ice

Table 4. Sequences of primers used for gene expression analysis

\begin{tabular}{|c|c|c|c|c|}
\hline Genes & Nucleotide sequence & Accession no. & Amplicon & $T_{\mathrm{m}}$ \\
\hline RAG1 & $\begin{array}{l}\text { F: 5'-AGCCAAAGCCAAACTCAGAA-3' } \\
\text { R: 5'-TCACGCACCATCTTCTCATC-3' }\end{array}$ & KC819903 & 150 & 60 \\
\hline Alp & $\begin{array}{l}\text { F: 5'-GCTGTCCGATCCCAGTGTAA-3' } \\
\text { R: 5'-CCAGTCTCTGTCCACACTGT-3' }\end{array}$ & - & 159 & 60 \\
\hline Twist2 & $\begin{array}{l}\text { F: 5'-CCCCTGTGGATAGTCTGGTG-3' } \\
\text { R: 5'-GACTGAGTCCGTTGCCTCTC-3' }\end{array}$ & - & 226 & 60 \\
\hline Mef2c & $\begin{array}{l}\text { F: 5'-GCGAAAGTTTGGCCTGATGA-3' } \\
\text { R: 5'-TCAGAGTTGGTCCTGCTCTC-3' }\end{array}$ & - & 180 & 60 \\
\hline Sox9 & $\begin{array}{l}\text { F: 5'-TCCCCACAACATGTCACCTA-3' } \\
\text { R: 5'-AGGTGGAGTACAGGCTGGAG-3' }\end{array}$ & - & 163 & 60 \\
\hline
\end{tabular}

F, forward; R, reverse. 
for $30 \mathrm{~min}$ in the dark using three cyanine dyes (Cy2, Cy3 and Cy5), and quenched with $1 \mathrm{~mm}$ lysine for $10 \mathrm{~min}$. Cy2 was used as the internal standard and was composed of equal amounts of proteins from each sample, whereas $\mathrm{Cy} 3$ and $\mathrm{Cy} 5$ were used to individually label the samples. The three labelled mixtures were combined and the total proteins $(75 \mu \mathrm{g})$ were added $\mathrm{v}-\mathrm{v}$ reducing buffer $(7 \mathrm{~m}$ urea, $2 \mathrm{~m}$ thiourea, $2 \%$ 1,4-dithiothreitol, $2 \% 3$-[(3-cholamidopropyl)dimethylammonio]-1-propanesulfonate (CHAPS) and $2 \%$ immobilised pH gradient (IPG) 4-7 buffer) for $15 \mathrm{~min}$ at room temperature in the dark. These mixtures were then cup-loaded on immobilised $\mathrm{pH}$ gradient strips $(24 \mathrm{~cm}, \mathrm{pH}$ 4-7; GE Healthcare) and passively rehydrated overnight with a rehydration buffer. The isoelectric focusing was performed with an Ettan ${ }^{\mathrm{TM}}$ IPGphor II isoelectric focusing unit (GE Healthcare) at $20^{\circ} \mathrm{C}$ for a total of $68000 \mathrm{Vh}$. IPG strips were then reduced $(1 \%$ 1,4-dithiothreitol) and alkalised (2.5\% iodoacetamide) in equilibration buffer just before being loaded onto a $10 \%, 24-\mathrm{cm}$, 1-mm-thick acrylamide gel. The strips were run in an Ettan $^{\mathrm{TM}}$ DALTsix electrophoresis unit (GE Healthcare) at constant $0.5 \mathrm{~W} / \mathrm{gel}$. The gels were then scanned with a Typhoon 9400 scanner (GE Healthcare) at wavelengths specific for the CyDyes ( $488 \mathrm{~nm}$ for $\mathrm{Cy} 2,532 \mathrm{~nm}$ for $\mathrm{Cy} 3$ and $633 \mathrm{~nm}$ for Cy5). Image analysis, with a resolution of $100 \mu \mathrm{m}$, was performed using the DeCyder BVA 5.0 software (GE Healthcare). Data were analysed using one-way ANOVA followed by the Tukey's post hoc test (using the Statistica 5.5 software, 2000; StatSoft, Inc.) when significant differences between groups were found $(P<0.05)$.

For peptide sequencing and protein identification, preparative gels including $150 \mu \mathrm{g}$ of proteins of mixed samples were performed ( $\mathrm{pH}$ 4-7 IPG strips, 10\% acrylamide). Gels were post-stained with $10 \%$ krypton overnight after 30 min of fixation, twice, in $40 \%$ ethanol and $10 \%$ acetic acid. The proteolytic digestion was performed on excised spots by the addition of $3 \mu \mathrm{l}$ of modified trypsin (Promega) suspended in $100 \mathrm{~mm}$ NH4HCO3 cold buffer. Proteolysis was performed overnight at $37^{\circ} \mathrm{C}$. The supernatants were collected and kept at $-20^{\circ} \mathrm{C}$ before analysis. Peptides were analysed by using nano-LC-ESI-MS/MS maXis Impact UHR-TOF (Bruker) coupled with a nanoLC UltiMate 3000 (ThermoFisher). Scaffold (version Scaffold-4.6.1; Proteome Software Inc.) was used to validate MS/MS-based peptide and protein identifications. All MS/MS samples were analysed using Mascot (version 2.4; Matrix Science) and X!Tandem (The GPM, thegpm.org). In all protein identifications, only significant hits as defined by Mascot probability analysis (using the algorithm Peptide Prophet) ${ }^{(59,60)}$ were considered initially, with a significance threshold set at $0 \cdot 01$. Proteins were functionally annotated using AgBase-Goanna ${ }^{(61)}$ as described in Roland et $a l^{(62)}$. The false discovery rate was always set at $0 \%$. The GO categories for biological processes were then sorted to determine the most common ones represented by the proteins identified. The mean number of proteomic spots detected per gel was 1917 (SD 498). A one-way ANOVA among the six experimental groups revealed twenty-seven spots with differential intensity at $P<0.05$. These spots were selected for statistical analyses and MS/MS identifications. Of the twenty-seven spots picked up for MS analysis, seventeen spots contained one protein identification per spot, and this led to the identification of fifteen different proteins.

\section{Statistics}

Percent data were arcsine-transformed before analysis. Experimental data were subjected to a one-way or two-way ANOVA and all pairwise multiple comparison of means test for determining significance of differences among the four treatment groups where applicable. Linear regression was used to determine correlation of dietary FA, phosphoglyceride content and larval content, as well as enzymatic activity. For larval survival, final weight, growth, FA, PL composition and enzymatic activity, the SigmaPlot 13.0 software was used and Holm Sidak test applied. For skeletal anomalies and related gene expression, the IBM SPSS Statistics 21 software was used and Tukey's test applied. For proteomics data, peptide sequencing and protein identification, the Statistica 5.5 software was used and Tukey's test applied. Levene's test was used to check for homogeneity of variance within the treatment groups. Values throughout the text are expressed as the mean values and standard deviations. In all statistical tests used, $P<0.05$ was considered statistically different. All analyses were based on larval samples obtained from triplicate groups, as described previously.

\section{Ethical standards}

The study has been conducted in accordance with national and international guidelines according to animal welfare ethics and approved. The ARRIVE guidelines for animal research studies have been followed.

\section{Results}

\section{Larval survival and growth}

From $15 \mathrm{DPH}$, there was an increase in daily larval mortality (data not shown), regardless of tanks and dietary codes. At the end of the trial (30 DPH), the sum of daily registered mortality suggested a survival ranging from 57 to $61 \%$ for the different tanks and without significant differences among dietary treatments ( $P \geq 0.553)$. However, based on the remaining number of alive larvae at the end of the trial, the actual survival was much lower (10-14\%), but neither statistically different $(P \geq 0.633)$.

Mean final larval weight at $30 \mathrm{DPH}$ ranged from 92 to $154 \mathrm{mg}$ wet weight (Fig. 1). Dietary inclusion of PL resulted in an increase in body weight, and additional supplementation of DHA (+EPA) in the form of Algatrium DHA 70 further increased weight. Thus, larvae fed the highest DHA and PL levels (diet PL3H3) showed the highest mean body weight, being significantly larger than in those fed PL1 $(P<0 \cdot 001)$, PL2 $(P \leq 0 \cdot 01)$ and PL1H1 $(P<0 \cdot 001)$. PL2H2 larvae were larger than those fed PL1 $(P<0.03)$ and PL1H1 $(P \leq 0 \cdot 001)$. Finally, PL2 and PL3 larvae were both larger than larvae fed PL1H1 ( $P \leq 0.04$ and $P \leq 0.01$, respectively). Overall, larval growth calculated as SGR was lowest for PL1H1 $(21 \cdot 2 \% / d)$ and highest for PL3H3 (24.3\%/d) (Fig. 1).

\section{Biochemical analysis}

There was a marked decrease in larval EPA and DHA larval composition from 0 to $10 \mathrm{DPH}$ and a corresponding increase in 


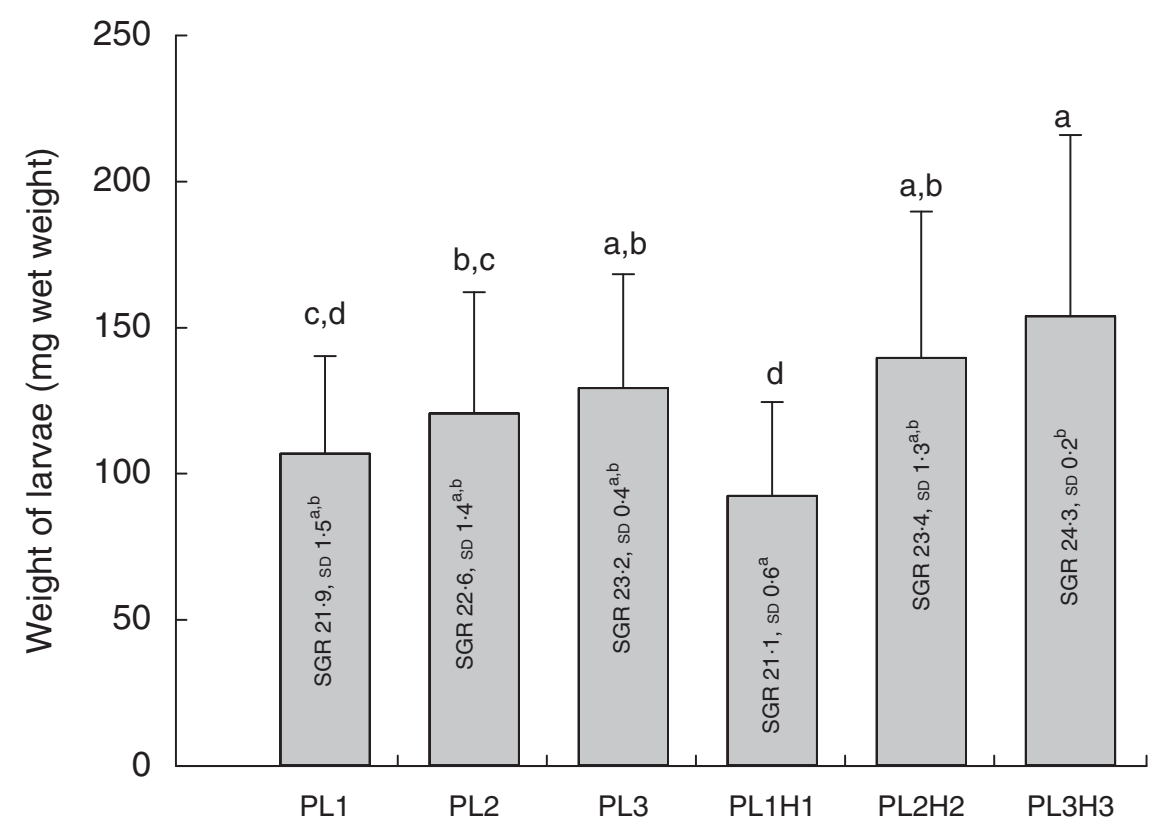

Fig. 1. Mean final body weight (mg wet weight; bars) of larvae fed experimental diets for $20 \mathrm{~d}$ (10-30 DPH). PL1, PL2 and PL3 (soyabean lecithin (SBL): 3,10 and $19 \%$ ); PL1H1, PL2H2 and PL1H3 (SBL: 3, 10 and 19\%) + Algatrium DHA 70: 0.55, 2.05 and 3.4\%. Final body weight values are pooled means of three tank replicates ( $n 35$ fish per tank), and standard deviations represented as vertical bars. Specific daily growth rate (SGR) (\%/d, values inside each bar, $n 3$ replicate tanks and standard deviations). ${ }^{\text {a,b,c,d }}$ Mean values for each diet group with unlike letters were significantly different $(P<0.05)$.

stearic acid (18:0), oleic acid $(18: 1)$ and $18: 3 n-3$ (Table 3 ). Larval FA content at $30 \mathrm{DPH}$ reflected dietary formulation and the increase in supplementation of PL and Algatrium DHA70 at the expense of olive oil, the main contributor of oleic acid (Table 3). The highest inclusion of Algatrium DHA 70 caused an increase of DHA content in larvae of PL3H3 about 2.5 times higher than that of PL3-fed larvae, whereas it was 1.5 times higher for EPA. An increased substitution of olive oil with SBL without LC-PUFA supplementation (PL2 and PL3) caused a significantly lower $n-3 / n-6$ in larvae compared with the other larval groups. An overall very significant larval/dietary correlation was observed for all larval groups for both oleic acid $\left(P<0.001 ; R^{2} 0.99 \cdot 6\right)$ and for DHA and EPA $\left(P<0.001, R^{2} 0.98\right)$ and $\left.P=0 \cdot 016, R^{2} 0 \cdot 80\right)$, respectively. Consequently, larval DHA: EPA was significantly correlated to diet DHA:EPA $(P<0.001$, $\left.R^{2} 0.97\right)$.

PC was the major PL class in diets and larvae (Fig. 2). In larvae, it constituted between 68 and $73 \%$ of the total PL content and was not significantly different between treatment groups $(P \geq 0 \cdot 241)$. An increase in the dietary content of $\mathrm{PC}$ increased the larval PC tissue content (Fig. 3a); however, this correlation was not significant for any of the two groups PL1PL3 $(P \geq 0 \cdot 14)$ or PL1H1-PL3H3 $(P \geq 0 \cdot 12)$. The phosphatidylethanolamine (PE) tissue content in larvae fed diet PL3H3 was significantly lower than in larvae fed PL2 and PL3 $(P<0.03$; Fig. 2). For larvae fed diets PL1, PL2 and PL3, an increase in the dietary PE content slightly increased larval content (Fig. 3b), but the correlation was not significant $(P \geq 0.62)$. However, for larvae fed diets PL1H1, PL2H2 and PL3H3, a strong negative tissue content correlation was observed with dietary PE content $(P=0.001)$ (Fig. 3b). For PL1-PL3 larval groups, a dietary increase in PI slightly increased larval PI content; however, the

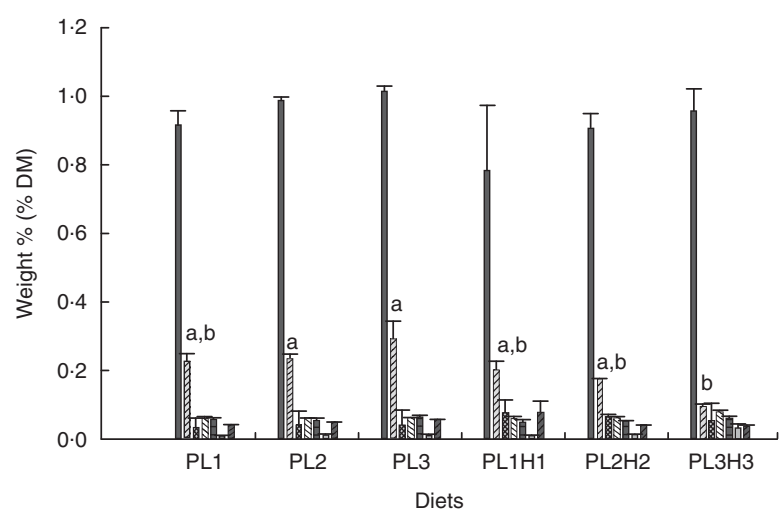

Fig. 2. Phospholipid class composition in larvae (\% DM mean values and standard deviations, $n 3$ replicate tanks) fed experimental diets for $20 \mathrm{~d}$ (10-30 DPH). PL1, PL2 and PL3 (soyabean lecithin (SBL): 3, 10 and 19\%). PL1H1, PL2H2 and PL1H3 (SBL: 3,10 and 19\%) + Algatrium DHA 70: 0.55, 2.05 and $3.4 \%$. $\square$, Phosphatidylcholine; $\square$, phosphatidylethanolamine; $\otimes$, phosphatidylinositol;

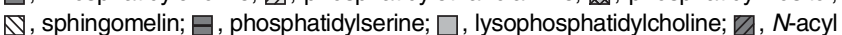
phosphatidylethanolamine. ${ }^{a, b}$ Mean values for each diet group with unlike letters were significantly different $(P<0.05)$.

correlation was not significant $(P \geq 0 \cdot 91)$. PL1H1-PL3H3 displayed on contrast a significant negative PI diet:PI larval correlation $(P=0.05)$. For other minor PL classes analysed, there were no significant differences among content in larvae between groups, although analysed contents in all diets were below detection.

\section{Digestive enzyme activity}

No significant differences were observed in larval pepsin activity (Table 5), despite a general trend for a higher activity in 
(a)

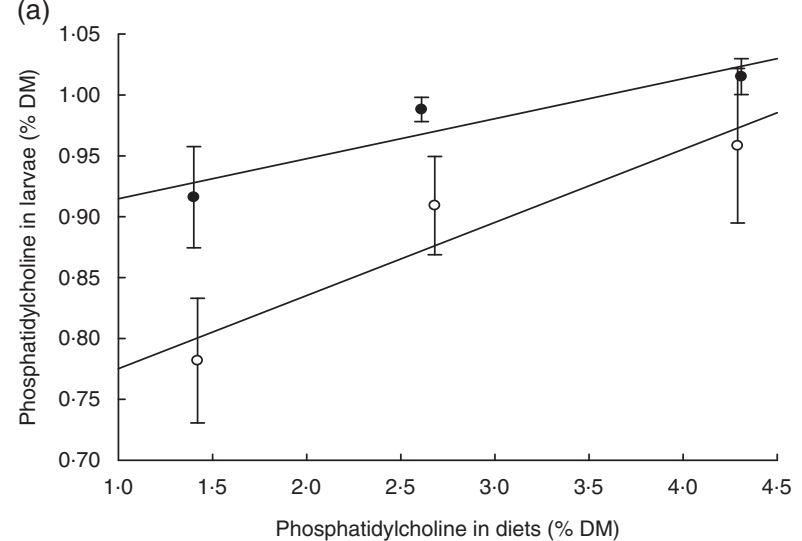

(b)

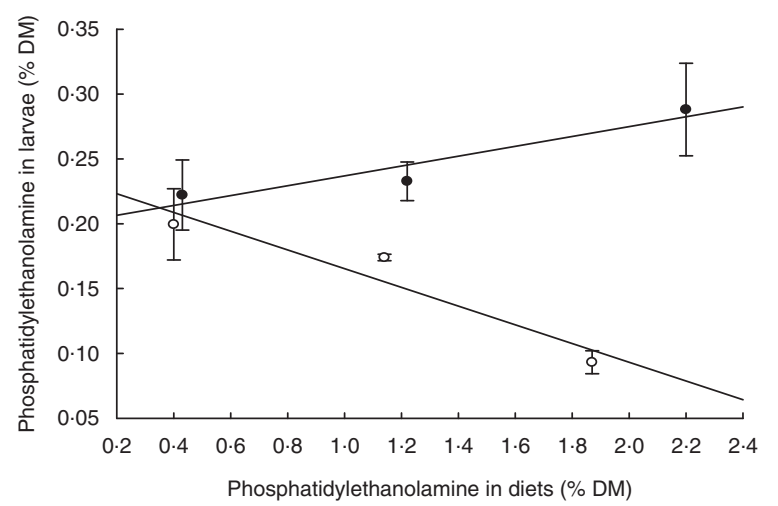

(c)

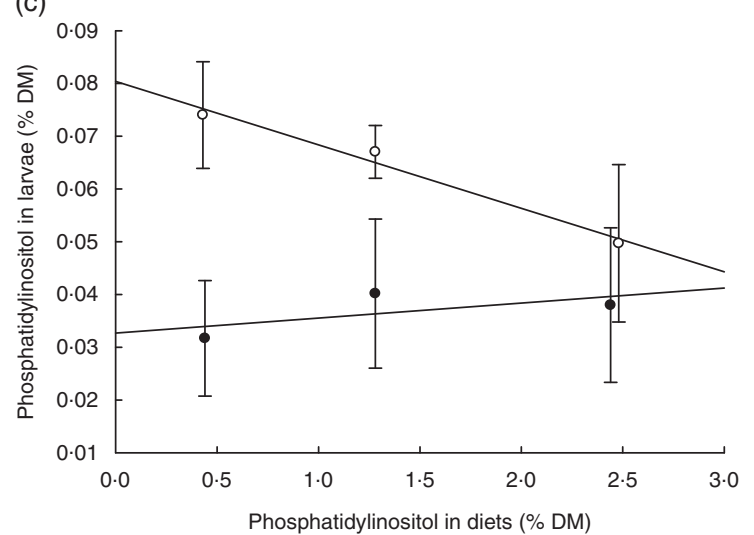

Fig. 3. (a-c) Dietary: larval tissue phospholipid class correlation when fed experimental diets for $20 \mathrm{~d}(10-30 \mathrm{DPH})$. Values are means $(n 3)$ replicate tanks. a: O, (PL1-PL3) y: $1.40 x+0.88 ; r^{2} \quad 0.88 ; O,(\mathrm{PL} 1 \mathrm{H} 1-\mathrm{PL} 3 \mathrm{H} 3)$ y. $1.42 x+0.72 ; r^{2} 0.91 ; b: 0$, (PL1-PL3) y. $0.43 x+1.98 ; r^{2} 0.91 ; O$, (PL1H1PL3H3) y: $0.40 x-0.238 ; r^{2}$ 0.92; c: 0 , (PL1-PL3) y. $1.44 x+0.03 ; r^{2} 0.42$; $\mathrm{O},(\mathrm{PL} 1 \mathrm{H} 1-\mathrm{PL} 3 \mathrm{H} 3)$ y: $0.43 x+0.08 ; r^{2} 0.97$

pikeperch larvae fed increased PL and DHA contents. In this sense, a significant positive linear correlation was found among the two parameters $\left(y=0.4971 x+45.397 ; r^{2} 0.934\right)$ (Fig. 4). Trypsin activity was significantly higher in larvae fed PL1H1 than in those fed PL2, PL3 and PL3H3 ( $P=0.003$; Table 5). Results showed that an increase in DHA, particularly from PL2 to $\mathrm{PL} 2 \mathrm{H} 2$, significantly reduced trypsin activity. In addition, a dietary increase in both PL and DHA from PL1H1 to PL3H3

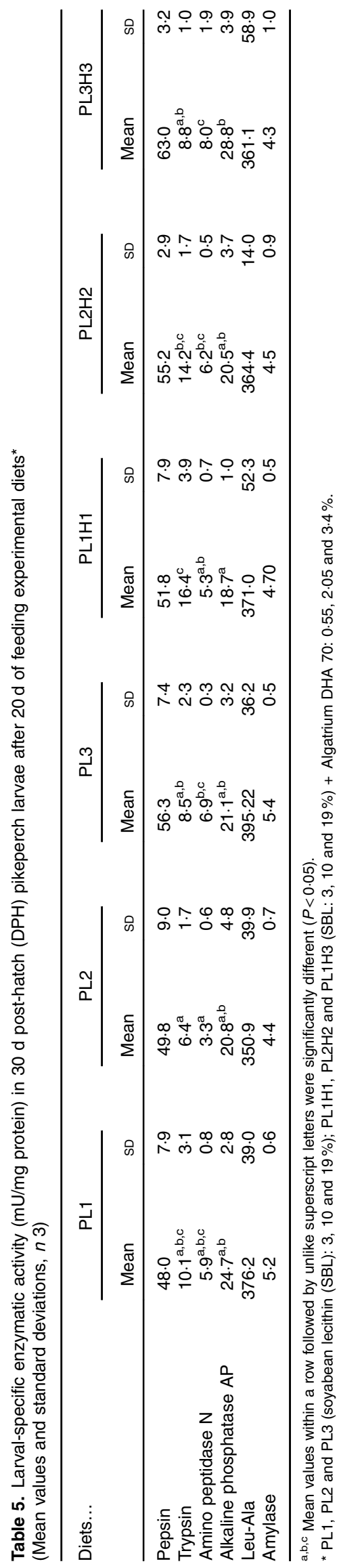




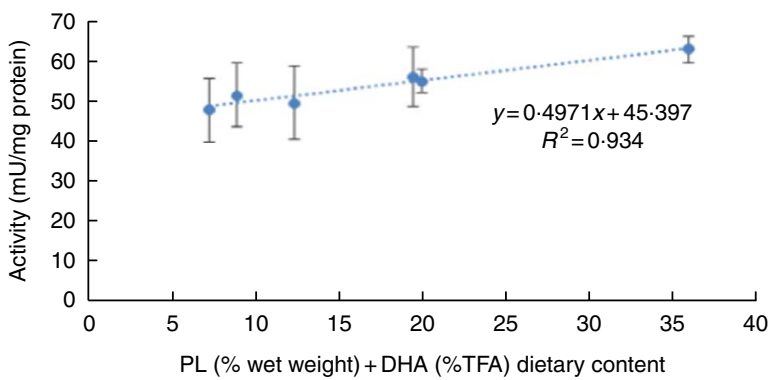

Fig. 4. Effect of dietary phospholipid (PL) (\% wet weight) and DHA (\% total FA (TFA)) on pepsin-specific activity in pikeperch larvae after $20 \mathrm{~d}$ of feeding experimental diets. Values are means $(n 3)$ replicate tanks and standard deviations represented by vertical bars.

significantly reduced trypsin activity $(P=0.003)$. On the other hand, despite the increase in dietary PL from PL1 to PL3, it did not significantly affect larval trypsin activity (Table 5). Aminopeptidase activity was lowest in larvae fed PL2 compared with those fed PL3, PL2H2 and PL3H3 $(P=0.001)$. An increase in dietary PL, particularly from PL2 and PL1H1 to PL3H3, significantly increased aminopeptidase activity. AP was significantly highest for PL3H3 larvae than for PL1H1 larvae $(P \leq 0 \cdot 038)$. Thus, despite the increase in dietary PL from PL1 to PL3, it did not significantly affect larval AP activity, but a dietary increase in both PL and DHA from PL1H1 to PL3H3 significantly increased the activity of this enzyme.

\section{Skeleton anomalies and related gene expression}

Overall there was a high incidence of severe anomalies, particularly those related with endochondral bones, such as cranium or dentary bones. The lowest incidence of severe anomalies was found in PL3H3 pikeperch, followed by PL3 (Table 6). An increase in dietary PL from PL1 to PL3 tended to reduce the incidence of severe anomalies. Moreover, a dietary increase in both PL and DHA from PL1H1 to PL3H3 significantly reduced the occurrence of severe anomalies. The incidence of maxillary anomalies was very low and only detected in larvae fed PL1H1 (Table 6). Dentary bone anomalies were significantly lowest in PL3 and PL3H3 larvae and highest in PL2 (Table 6). A similar trend was found in branchiostegal rays (Table 6) and cranial anomalies incidences (Table 6) that were significantly lowest in larvae fed diets PL3H3 and PL3 and highest in PL1 and PL1H1. Indeed, a highly significant inverse correlation was found between the dietary PL content or PC content and the incidence of cranial anomalies $\left(r^{2} 0.98 ; P<0.001\right.$ or $r^{2} 0.98, P<0.001$, respectively) or severe anomalies $\left(r^{2} 0.89, P<0.01 ; r^{2} 0.88\right.$, $P<0 \cdot 01$, respectively). No significant differences were found in any of the other anomalies studied.

Expression of bone morphogenesis-related genes did not show a clear effect of the different treatments. In fact, no statistical differences were found between larvae fed the different diets for the four genes analysed (Table 7).

\section{Proteomics}

Of fifteen different identified proteins, nine proteins displayed a differential intensity between treatments (Tukey's post hoc test

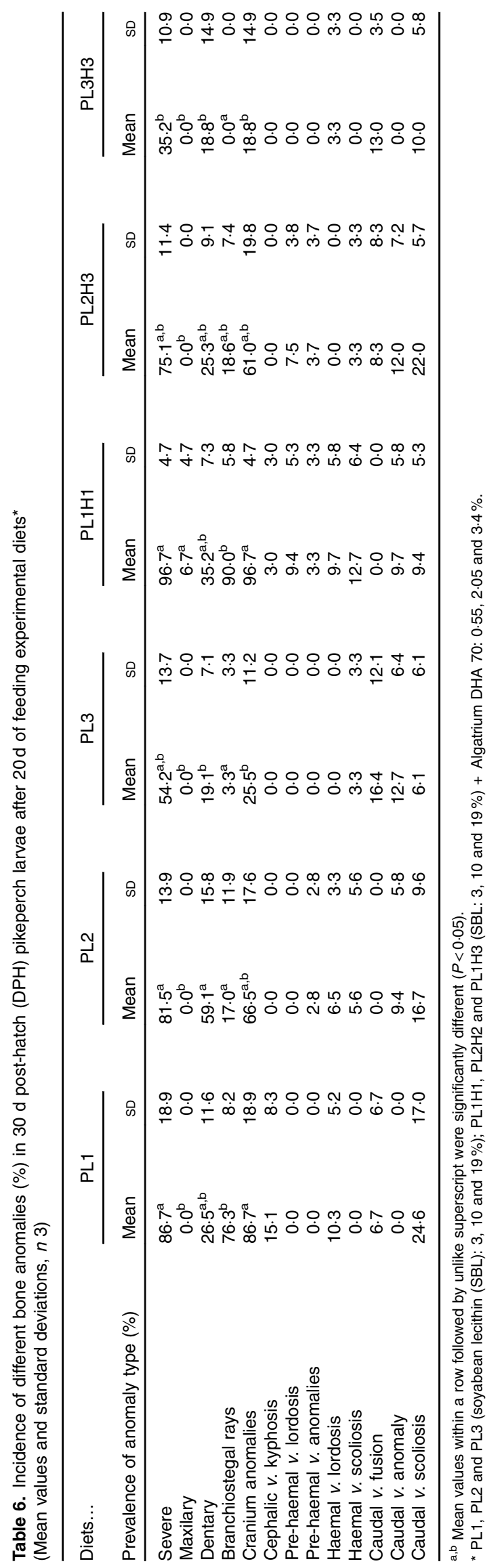


Table 7. Gene expression in $30 \mathrm{~d}$ post-hatch (DPH) pikeperch larvae after $20 \mathrm{~d}$ of feeding experimental diets* (Mean values and standard deviations, $n 3$ )

\begin{tabular}{|c|c|c|c|c|c|c|c|c|c|c|c|c|}
\hline \multirow[t]{2}{*}{ Diets... } & \multicolumn{2}{|c|}{ PL1 } & \multicolumn{2}{|c|}{ PL2 } & \multicolumn{2}{|c|}{ PL3 } & \multicolumn{2}{|c|}{ PL1H1 } & \multicolumn{2}{|c|}{ PL2H2 } & \multicolumn{2}{|c|}{ PL3H3 } \\
\hline & Mean & SD & Mean & SD & Mean & SD & Mean & SD & Mean & SD & Mean & SD \\
\hline Alp & 2.03 & $2 \cdot 70$ & 0.81 & 0.28 & 1.05 & 0.85 & 3.02 & 2.08 & 0.68 & 0.79 & 1.28 & 1.47 \\
\hline Twist2 & 1.33 & $1 \cdot 18$ & 0.24 & 0.07 & 0.79 & 0.79 & 0.51 & 0.48 & 0.15 & 0.09 & 0.08 & 0.02 \\
\hline Mef2c & 1.15 & 0.75 & 0.41 & 0.14 & 1.41 & 1.55 & 0.61 & 0.52 & 0.12 & 0.07 & 0.07 & 0.02 \\
\hline Sox9 & 1.11 & 0.64 & 0.53 & 0.13 & 1.08 & 0.78 & 1.52 & 1.93 & 0.27 & 0.19 & 0.14 & 0.01 \\
\hline
\end{tabular}

${ }^{*}$ PL1, PL2 and PL3 (soyabean lecithin (SBL): 3, 10 and 19\%); PL1H1, PL2H2 and PL1H3 (SBL: 3, 10 and 19\%) + Algatrium DHA 70: 0.55, 2.05 and 3.4\%.

Table 8. Protein differentially expressed in liver of $30 \mathrm{~d}$ post-hatch (DPH) pikeperch larvae after $20 \mathrm{~d}$ of feeding experimental diets

\begin{tabular}{|c|c|c|c|c|c|c|c|}
\hline Spot no. & Accession no. & Protein identification & Species & $\begin{array}{l}\text { Number of } \\
\text { matched } \\
\text { peptides }\end{array}$ & $\begin{array}{l}\text { Theoretical } \\
\text { PI/MW }\end{array}$ & $P$ & Fold change \\
\hline 794 & AOAOF8AHC2 & Glucose-regulated & Larimichthys crocea & 5 & $5 \cdot 41 / 82$ & 0.007 & -1.70 in PL3H3/PL2 \\
\hline \multirow[t]{2}{*}{518} & AOA0F8AWU1 & Glucose-regulated protein (GRP94) & Larimichthys crocea & 7 & $4 \cdot 76 / 91$ & 0.031 & -1.48 in PL1H1/PL2 \\
\hline & UPI000557CE3B & Glucose-regulated protein (GRP94) & Notothenia coriiceps & 6 & $4.73 / 92$ & & -1.52 in PL3H3/PL2 \\
\hline \multirow[t]{3}{*}{369} & AOA0F8AWU1 & Glucose-regulated protein (GRP94) & Larimichthys crocea & 6 & $4.76 / 91$ & 0.033 & -1.63 in PL3H3/PL1 \\
\hline & UPI000557CE3B & Glucose-regulated protein (GRP94) & Notothenia coriiceps & 5 & $4.73 / 92$ & & \\
\hline & UPI00055340E4 & Ubiquitin carboxyl-terminal hydrolase 5 & Notothenia coriiceps & 3 & $4.98 / 88$ & & \\
\hline \multirow[t]{3}{*}{795} & UPI000556131D & Fatty acid synthase-like & Notothenia coriiceps & 4 & $5 \cdot 66 / 54$ & 0.002 & 4.36 in $\mathrm{PL} 1 / \mathrm{PL} 3 \mathrm{H} 3$ \\
\hline & & & & & & & $\begin{array}{l}3.65 \text { in PL2/PL3H3 } \\
3.54 \text { in PL3/PL3H3 }\end{array}$ \\
\hline & & & & & & & 3.50 in PL1H1/PL3H3 \\
\hline 1102 & G3P216 & ATP-citrate synthase & Gasterosteus aculeatus & 3 & $7 \cdot 80 / 120$ & 0.036 & -2.60 in PL3H3/PL2 \\
\hline \multirow[t]{3}{*}{1633} & H2U634 & Non-specific lipid-transfer protein & Takifugu rubripes & 3 & $8 \cdot 11 / 59$ & 0.042 & -2.03 in $\mathrm{PL} 3 \mathrm{H} 3 /$ \\
\hline & UPI000551760C & Non-specific lipid-transfer protein & Notothenia coriiceps & 2 & $6 \cdot 58 / 58$ & & PL1H1 \\
\hline & H2SWA2 & $\begin{array}{l}\text { Hydroxysteroid dehydrogenase-like } \\
\text { protein } 2\end{array}$ & Takifugu rubripes & 2 & $6.03 / 37$ & & \\
\hline \multirow[t]{3}{*}{1232} & G8G8Y1 & Keratin 8 (fragment) $n 2$ & Epinephelus coioides & 9 & $4.72 / 41$ & 0.035 & $-2 \cdot 27$ in PL2H2/PL1 \\
\hline & G3NI19 & Keratin type II cytoskeletal 8-like & Gasterosteus aculeatus & 9 & $5 \cdot 22 / 60$ & & -2.33 in PL3H3/PL1 \\
\hline & Q4QY72 & Type II keratin E3-like protein & Sparus aurata & 4 & $4.89 / 39$ & & \\
\hline 1376 & UPI00054B498F & Protein disulphide-isomerase & Larimichthys crocea & 5 & $4.61 / 57$ & 0.047 & NS \\
\hline \multirow[t]{2}{*}{1947} & U3LRB6 & Protein disulphide-isomerase & Dicentrarchus labrax & 3 & $5 \cdot 39 / 56$ & 0.005 & $\begin{array}{l}1.85 \text { in PL2/PL1 } \\
1.99 \text { in PL2H2/PL1 }\end{array}$ \\
\hline & & & & & & & 1.67 in PL2/PL1H1 \\
\hline
\end{tabular}

$\mathrm{PI}$, isoelectric point; MW, molecular weight.

$(P<0.05)$, Table 8$)$. Fatty acid synthase (FAS) is primarily responsible for the synthesis of palmitate $(16: 0)$ (i.e. SFA with 12,14 or 16 carbons can be synthesised), which can be further elongated and/or desaturated as it is the main reactor in lipogenesis and FA synthesis. Among the identified proteins, FAS was significantly down-regulated in PL3H3 larvae compared with larvae of PL1, PL2 and PL1H1 (4.36-, 3.65- and 3.50-fold respectively, $P<0 \cdot 01)$, suggesting a negative relation with DHA levels in larvae (Table 3 ). Besides, for a given dietary PL content $(14.4 \%)$, an increase in total dietary $n$-3 LC-PUFA from 10.5 to $27.9 \%$ (i.e. Table 2 ) significantly down-regulated FAS expression; this protein was over-expressed in PL3 larvae compared with PL3H3 (3.54-fold, $P=0.002)$. However, the analysis showed that, for the same level of low total $n-3$ PUFA content $(7 \cdot 7 \%)$, the increase in dietary PL content did not significantly affect FAS expression (comparison between PL2 and PL1H1 larvae; Table 2).

Another protein related to lipid metabolism, ATP-citrate synthase, was also under-expressed in $\mathrm{PL} 3 \mathrm{H} 3$ larvae compared with PL2 larvae (2.60-fold, $P<0 \cdot 05)$. Similarly, a high
PL and LC-PUFA dietary content (diet PL3H3) led to an under-expression for spot 1633, in which two lipid transfer proteins were identified, the non-specific lipid transfer protein and the hydroxysteroid dehydrogenase-like protein 2 (HSDL2), as compared with PL1H1 (1.63-fold, $P=0.03$ ). In comparison with larvae reared on PL2, larvae fed PL3H3 displayed a decrease in abundance for two proteins involved in endoplasmic reticulum (ER) stress: the glucose regulated protein (Grp) and the glucose-regulated 94 (Grp94) (Hsp90) (1·70-fold, $P=0.007$, and 1.52 -fold, $P=0.03$, respectively). A similar pattern of protein expression occurred for Grp94 in PL1H1 larvae compared with PL2 (1.48-fold, $P=0.03)$. In addition, spot number 369 displayed a differential intensity between larval groups PL3H3 and PL1 (1.63-fold, $P=0.03)$, in which both Grp94 and a function ubiquitin carboxyl-terminal hydrolase 5 were identified. Two spots were identified as protein disulphide-isomerase (PDI) (spots 1376 and 1947); according to Tukey's post hoc test, only spot 1947 displayed a differential intensity that was lower in larvae fed PL1 compared with PL2H2 and PL2 treatment (1.99- and 1.85-fold, $P=0.005)$. Larvae fed 
PL2 showed also an increase in its abundance compared with PL1H1-fed larvae (1.67-fold, $P=0.005)$. Last, larvae reared on PL1 showed an increase in abundance for a spot identified as Keratin - a cytoskeletal and structural protein - in comparison with PL2H2 and PL3H3 larvae (2.27- and 2.33-fold respectively, $P=0 \cdot 03)$.

\section{Discussion}

Survival was reduced by cannibalism in all tanks, in agreement with previous observations ${ }^{(2,3)}$. Larval growth was generally high, even when fish were fed the lowest PL and $n-3$ LC-PUFA dietary levels. An increase in dietary PL levels up to $8 \%$ markedly enhanced larval weight, in agreement with a recent unpublished study with these same diets, where pikeperch larvae fed the lowest PL levels (3.70 and 3.73\%) showed a significantly lower growth. However, elevation of dietary PL from 8 to $14.5 \%$ did not further increase fish growth significantly. These results are in agreement with the optimum PL requirement previously defined for pikeperch (9.5\%) fed SBL ${ }^{(2)}$. Similarly, PL requirements for gilthead seabream (Sparus aurata) fed SBL were approximately $8 \%$, when larvae were fed five dietary PL levels (4.9-9.6\%) ${ }^{(21)}$. Pikeperch growth promotion by an increase in dietary PL may be related to a higher feed intake as shown in gilthead seabream and prawn (Penaeus monodon) ${ }^{(24,63,64)}$. Moreover, an increase in dietary PL tended to increase larval PC contents. This increase in PC at higher dietary PL contents would be in agreement with previous studies showing that $\mathrm{PC}$ is the main product of $\mathrm{PL}$ synthesis in fish enterocyte ${ }^{(38)}$ and comprises up to $95 \%$ of the $\mathrm{PL}$ found in VLDL ${ }^{(65)}$. Moreover, $\mathrm{PC}$ has been long considered the most effective PL to promote larval growth ${ }^{(12)}$. For instance, dietary supplementation with PC, but not PE, stimulated feeding activity in gilthead seabream larvae, probably through the ingestion of the trimethyl group of the choline base of PC that binds to receptor gustatory cells ${ }^{(66)}$. Nevertheless, growth improvement in pikeperch larvae fed increased PL dietary levels could also be related to an improved lipid transport in agreement with previous studies. For instance, in gilthead seabream, fish fed diets without lecithin accumulated lipid vacuoles in the basal zone of intestinal enterocytes and caused steatosis in hepatic tissue, whereas supplementation with SBL reduced accumulation $^{(37)}$ and enhanced lipoprotein synthesis ${ }^{(20)}$

An increase in dietary PL from 3.72 up to $8.19 \%$ did not significantly affect the incidence of anomalies, which is in agreement with previous studies with pikeperch and similar PL levels (1.4-9.5\%) supplemented with $\mathrm{SBL}^{(2)}$. Similar results were found in gilthead seabream, where an increase in dietary SBL did not reduce bone anomalies. ${ }^{(41)}$ However, in the present experiment, a further dietary PL increase up to 14.38 significantly reduced the incidence of severe skeletal anomalies, and tended to be lowest in fish fed increased DHA dietary levels. This was more evident on anomalies affecting endochondral bones, such as the cranium, where an increase in dietary PL reduced the prevalence of these anomalies. These results are in agreement with those obtained in European sea bass (Dicentrarchus labrax) ${ }^{(67)}$, although the incidence of anomalies was much lower in seabass than in pikeperch.
It should be noticed that the seabass study used higher levels of PC and PI (35 and $16 \mathrm{mg} / \mathrm{kg}$ respectively). Despite the differences in prevalence of skeletal anomalies, bone anomaly reduction by $\mathrm{PL}$ was not related to the relative expression of the bone-development-related genes studied, such as alp (early mineralisation indicator), twist2, mef2c or sox 9 (endochondral bone-development-related genes). This lack of effect could be because of an earlier origin of the anomalies during the first part of the feeding trial, when cartilage was being developed and bones ossified. At the final sampling (30 DPH), bone mineralisation in pikeperch was almost completed. Indeed, in gilthead seabream, an increase in SBL up to $12 \%$ significantly up-regulated alp $^{(21)}$. Reduction of bone anomalies by increased PL dietary contents has been related to the specific increase in dietary $\mathrm{PI}^{(68)}$, as the second messenger inositol-3-phosphate regulates $\mathrm{Ca}$ mobilisation from the $\mathrm{ER}^{(16)}$ and would stimulate osteocalcine production $^{(12)}$.

In addition to growth improvement, dietary SBL supplementation markedly affected pikeperch larvae FA composition, elevating the $18: 2 n-6$, an essential FA for freshwater fish, as well as $18: 3 n-6$ and $20: 3 n-6$, products of $\delta$ - 6 -desaturase and elongase activity. However, 20:4n-6, a product of $\delta$-5-desaturase activity, was not increased; this was in agreement with the low LC-PUFA biosynthetic ability of pikeperch larvae (unpublished results).

Combined supplementation of SBL up to $14.51 \%$ DM PL with $n$-3 LC-PUFA (1.0\% DM DHA and $0 \cdot 16 \%$ DM EPA; i.e. $1 \cdot 17 \%$ LC PUFA) in the form of TAG led to the highest growth and lowest anomalies incidence, improving digestive enzyme activities and liver proteomics. This could be related to either a specific effect of the FA or a combined effect of PL and FA. The latter seems likely, as diets with lowest PL inclusion (3.70 and 3.73\%) but different LC PUFA content (i.e. $0 \cdot 17 \% \mathrm{EPA}+0 \cdot 39 \%$ DHA $v \cdot 0 \cdot 3 \%$ $\mathrm{EPA}+0.98 \%$ DHA) both lead to a relatively lower growth. A negative effect on growth by a high inclusion level of olive oil; $18: 1 n-9$ in both of these diets, however, cannot be excluded as the gradual substitution of olive oil with soya lecithin caused a 3-fold increase in tissue linoleic acid, 18:2n-6 levels and a concurrent 2-fold decrease in tissue oleic acid, 18:1n-9 content. 18:2n-6 may have a growth-promoting effect or a different metabolic fate as compared with $18: 1 n-9$, despite the fact that C14-labelled FA analyses have indicated no elongation or desaturation capability in pikeperch larvae (unpublished results). The optimal levels of EPA and DHA in marine fish larvae has been estimated to be about $3 \%$ of dietary $\mathrm{DM}^{(69)}$, whereas for pikeperch larvae an optimal level of $1.2 \%$ DM has been suggested, based on experiments with SBL without $n-3$ LC-PUFA and fish gonad lecithin with $n-3$ LC-PUFA $^{(30)}$. In addition, $1.2 \%$ LC-PUFA is very similar to the $1.17 \%$ estimated to be optimal in this experiment - in the presence of $14.5 \% \mathrm{PL}$ supplemented as SBL. In agreement with previous studies in marine fish larvae ${ }^{(12,16,24,32,37,67,70)}$, marine PL rich in $n$-3 LCPUFA could be more effective as a source of essential FA than SBL supplemented with $n-3$ LC-PUFA. Izquierdo et al. ${ }^{(24)}$ compared the effect of four isoenergetic, isoproteic and isolipidic diets with either two levels of SBL substituted by oleic acid and supplemented with EPA and DHA in a TAG form or by two levels of marine PL in twenty-five DPH larval seabream. 
These authors found that PL, regardless of the SBL or marine origin, increased diet ingestion, but also that there was a higher incorporation of $n$ - 3 LC-PUFA into the larval polar lipids when these FA were provided in the form of marine PL, which was related with growth improvement ${ }^{(24)}$. A combined increase in dietary PL and $n$-3 LC-PUFA interestingly reduced relative PE contents in the larvae, probably with a higher DHA content given the affinity of diacylglycerol ethanolamine phosphotransferase for $\mathrm{DHA}^{(38)}$, which could have been related to the proportional increase in PC stimulated by PL and $n-3$ LCPUFA $^{(24)}$. An increase in both dietary PL and $n-3$ LC-PUFA seemed to cause an inverse relationship $(P=0.05)$ to PI content in larvae. Dietary PI is known to be more effective in reducing deformities than PC. PI and its derivatives have a structural role in the membrane moduling protein kinase $\mathrm{C}$ activity, as well as calcium entry into the cell from nuclear reservoirs ${ }^{(71)}$, and is believed to be influencing ontogeny of bone synthesis and mineralisation $^{(68)}$. The observed lowest degree of malformation in pikeperch larvae with a combined increase of PL and DHA may involve dietary levels of PI; however, the physiological processes need further investigation.

In the present study, increased PL and $n$ - 3 LC-PUFA enhanced the activities of the brush border membrane enzymes, AP and aminopeptidase, in agreement with previous studies $^{(2,22,30,32,72)}$. This enhanced enzymatic activity is associated with a higher maturation of the gut followed by growth improvement ${ }^{(2,22,32,73-75)}$, and more precisely with a faster maturational process of the enterocytes ${ }^{(76)}$. Indeed, in fish larvae, enterocyte morphology is influenced by the developmental stage and dietary composition ${ }^{(34,35,74)}$. In our study, the acceleration of gut developmental processes in larvae fed high PL was further supported by the advanced ontogenetical stage in larvae fed high PL suggested by proteomics finding of keratin type II expression.

Trypsin activity displayed an opposite pattern to that of the brush border enzymes in the present study, but also to the pepsin activity. Pancreatic secretion can be modulated by $\mathrm{FA}^{(32,77)}$, as well as by PL. Indeed it has been shown that an improvement in digestion efficiency in high PL-fed fish resulted in an enhanced secretion of cholecystokinine CCK, the primary regulator of pancreatic secretion ${ }^{(21,78)}$. These authors suggested that an increased PUFA content in the biomembrane of larval tissues and intestinal lumen could modulate CCK function ${ }^{(21,79)}$. In this regard, an antagonistic feedback mechanism between CCK and trypsin activity was demonstrated in cod larvae ${ }^{(80)}$, which further supports the existence of a CCK-releasing factor $^{(81)}$. Despite no significant difference was recorded in pepsin activity, it should be noted that the lowest trypsin activity was associated with the higher pepsin activity. In fact, during the early larval ontogeny, a progressive shift in relative activity from alkaline to acid proteases is observed ${ }^{(82-85)}$. As a consequence, the decrease in tryptic activity could be linked to the enhancement of acidic digestion in the stomach of the largest pikeperch larvae.

Liver proteomics were also affected by the combined elevation of PL and $n$ - 3 LC-PUFA. For instance, FAS expression was down-regulated in larvae fed PL3H3 compared with PL1 and PL1H1, suggesting a higher energy demand of the smallest larvae. Moreover, FAS seemed to be more regulated by LCPUFA content than by PL levels, probably as a positive effect of DHA supplementation. Most of the previous studies of FAS regulation have focused on the control of gene expression, suggesting that LC-PUFA may decrease FAS expression through the inhibition of SREBP-1c ${ }^{(86,87)}$. Besides, FAS appears to participate in liver TAG metabolism by promoting $\beta$-oxidation of FA through the activation of PPAR $\alpha$ under nutrient-deficient conditions $^{(88)}$. Indeed, FAS is required for generating the PL 1-palmitoyl-2-oleoyl-sn-glycerol-3-phosphocholine (16:0/18: 1GPC), an endogenous ligand for PPAR $\alpha^{(89)}$. However, this interpretation should be considered carefully, taking into account the changes in FAS activity without corresponding changes in FAS protein levels. Equally, we also observed a low expression of ATP-citrate synthase in larvae fed the highest $n-3$ PUFA/PL diet, which is the primary enzyme responsible for the synthesis of cytosolic acetyl-CoA considered as the principal building block of FA, as acetyl-CoA is converted to malonyl-CoA by acetyl CoA carboxylase.

Another marked effect of dietary PL and $n-3$ LC-PUFA in pikeperch was the down-regulation of the expression of proteins involved in transfer and exchange of PL and cholesterol such as the non-specific lipid transfer protein and the HSDL2. The non-specific lipid transfer protein, more commonly denoted as sterol carrier protein 2 (SCP2), transfers PL between membranes and sterols (cholesterol and glycolipids) ${ }^{(90-92)}$. This peroxisomal protein is able to bind fatty acyl-CoA, where it is probably involved in the $\beta$-oxidation of $\mathrm{FA}^{(93-95)}$. Furthermore, its association with the $\beta$-oxidation complex could be important for the protection of unsaturated FA intermediates against oxidative $\operatorname{attack}^{(96)}$. It is well known that HSDL2 is the product of one of the sterol carrier protein 2 (SCP2) domain encoding genes $^{(97)}$, thus pointing to its potential involvement in the transport and/or metabolism of FA. Similarly, the peroxisomal localisation of human HSDL2 may suggest also an involvement in fatty acid metabolism ${ }^{(93)}$. Previous studies demonstrated that the promoter region for SCP2-encoded gene contains several regulatory domains including a peroxisomal proliferator response element PPRE, which is the specific DNA region of target genes that bind with $\operatorname{PPAR}^{(98,99)}$. Therefore, in this study, we hypothesise that the down-regulation of SCP2 observed in this study in PL3H3 larvae may be explained by a deficient $\operatorname{PPAR} \alpha$ activation owing to the decrease in FAS expression in these larvae as a response to the high dietary $n$ - 3 LC-PUFA (explained above). Consistently with this hypothesis, in a recent study, SCP2 gene expression was down-regulated after colon cancer cell transplantation in mice fed high DHA. Besides, the same authors observed a decrease of SCP2 expression in cultured colon cancer cells, HCT-15, after a 48-h treatment with $\mathrm{DHA}^{(100)}$.

PDI is a multifunctional protein that acts as a catalyst of disulphide bond formation, reduction and isomerisation of newly synthesised proteins ${ }^{(101,102)}$. In this experiment, an increase in abundance of PDI was observed in the liver of larvae fed PL2 and PL2H2 compared with PL1. A similar pattern of expression was reported in mice fed low- and high- $n-3$ LC-PUFA diets, suggesting an increase in protein synthesis in high- $n-3$ LC-PUFA animals ${ }^{(103)}$. On the other hand, in this 
experiment, a significant difference in PDI expression was recorded between larvae fed the same $n$-3 LC-PUFA - PL2 compared with PL1HI. The over-expression in PDI in the biggest larvae may reflect an enhanced protein synthesis through high-energy mobilisation for growth. In this sense, Hamza et $a l .{ }^{(18)}$ suggested the enhanced ability to allocate nutrient and energy into tissue formation in pikeperch larvae fed high PL. Moreover, PDI has a chaperone activity under stress; it is synthesised in response to the unfolded protein response pathway (UPR) in the ER lumen ${ }^{(104)}$, pointing its important role in the maintenance of ER homoeostasis ${ }^{(105)}$. In this respect, PDI overexpression in PL2 might indicate an ER stress ${ }^{(106)}$. Similarly, Grp and Grp94, known by their major roles during UPR to maintain ER homoeostasis ${ }^{(107)}$, were over-expressed in PL2. Grp94 is a hallmark of the UPR response defined as an HSP90 family member commonly denoted endoplasmin ${ }^{(108)}$. This protein together with PDI and other folding factor components form a functional folding network under a coordinate transcriptional regulation $^{(108)}$. As mentioned above, both Grp and Grp94 were over-expressed in larval group PL2 compared with PL3H3 in this study, suggesting a reduced sensitivity to stress thanks to the dietary PL supplementation ${ }^{(72,109)}$. Interestingly, the same pattern of expression regarding the response to the dietary PL was observed in PL1 and PL3H3 treatments. Indeed, apart from Grp94, another protein was identified, that is, the ubiquitin carboxyl-terminal hydrolase L5, which participates in a cellular pathway responsible for the degradation of misfolded and damaged proteins involved in the ubiquitin proteasome system ${ }^{(110)}$. However, the over-expression of Grp94 in PL2 as compared with PL1H1 (same $n-3$ LC-PUFA content) supports the importance of a balanced inclusion of both PL and $n-3$ LCPUFA in the formulation of pikeperch diets.

The reduction in the different isoforms of the keratin type II detected in liver of pikeperch fed increased PL and $n-3$ LC-PUFA could indicate an advanced developmental stage in these larvae, as it has been shown that keratin type II displays a differential expression pattern during the early ontogeny of fish, with a higher abundance in younger $\operatorname{larvae}^{(111)}$.

\section{Conclusion}

In conclusion, this study confirms the importance of high PL levels of approximately $8 \%$ in diets for pikeperch, as well as the positive additional beneficiary effect of supplementation with DHA + EPA in the form of concentrated TAG in otherwise identical formulated diets. Thus, combined supplementation of SBL up to $14.51 \%$ DM PL with $n$-3 LC-PUFA (1.00 \% DM DHA and $0.16 \%$ DM EPA) in the form of TAG led to the highest growth and lowest anomalies incidence, which improved digestive enzyme activities and liver proteomics. Overall, the results denote that essential FA may be directly supplemented as TAG to have a beneficial effect in pikeperch larvae development. Confirmatory larval studies in pikeperch larvae should involve effects of TAG- and PL-supplemented LC-PUFA and resultant FA composition in PL and NL tissue fractions.

\section{Acknowledgements}

The authors thank Thorsten Buchen and Rute Azevedo, Spectral Service AG, Germany, for their kind assistance regarding phospholipid ${ }^{31} \mathrm{P}$ NMR spectroscopic analyses.

This study has been supported under the framework of the European Union Seventh Framework Programme project DIVERSIFY (KBBE-2013-07 single stage, GA 603121) titled 'Exploring the biological and socio-economic potential of new/ emerging fish species for the expansion of the European aquaculture industry'. A part of the research was funded by Agencia Canaria de Investigación, Innovación y Sociedad de la Información (TESIS 2015010078), for a predoctoral grant for D. D. for PhD studies.

I. L. performed the experiment and several analyses, and contributed to writing the manuscript. N. E. was in charge of several analyses of enzymes and liver proteomics and contributed to writing the manuscript. M. S. I. and D. D. performed the analysis on gene expression and anomalies and helped in revising the manuscript. B. W. H. and P. K. were involved in the design of the study and in the analysis of lipids, and they critically reviewed the manuscript.

The authors declare that there are no conflicts of interest.

\section{References}

1. Dalsgaard AJT, Lund I, Thorarinsdottir R, et al. (2013) Farming different species in RAS in Nordic countries: current status and future perspectives. Aquac Eng 53, 2-13.

2. Hamza N, Mhetli M, Ben Khemis I, et al. (2008) Effect of dietary phospholipid levels on performance, enzyme activities and fatty acid composition of pikeperch (Sander lucioperca) larvae. Aquaculture 275, 274-282.

3. Lund I \& Steenfeldt SJ (2011) The effects of dietary long chain essential fatty acids on growth and stress tolerance in pikeperch larvae (Sander lucioperca L.). Aquac Nutr 17, 191-199.

4. Lund I, Høglund E, Ebbesson LO, et al. (2014) Dietary LCPUFA deficiency early in ontogeny induces behavioural changes in pikeperch (Sander lucioperca) larvae and fry. Aquaculture 432, 453-461.

5. Czesny S, Kolkovski S, Dabrowski K, et al. (1999) Growth, survival, and quality of juvenile walleye Stizostedion vitreum as influenced by $n-3$ HUFA enriched Artemia nauplii. Aquaculture 178, 103-115.

6. Xu XL \& Kestemont P (2002) Lipid metabolism and FA composition in tissues of Eurasian perch (Perca fluviatilis) as influenced by dietary fats. Lipids 37, 297-304.

7. Azarm HM, Kenari AA \& Hedayati M (2013) Effect of dietary phospholipid sources and levels on growth performance, enzymes activity, cholecystokinin and lipoprotein fractions of rainbow trout (Oncorbynchus mykiss) fry. Aquac Res $\mathbf{4 4}$, 634-644.

8. Cai Z, Feng S, Xiang X, et al. (2016) Effects of dietary phospholipid on lipase activity, antioxidant capacity and lipid metabolism-related gene expression in large yellow croaker larvae (Larimichthys crocea). Comp Biochem Physiol B 201, 46-52.

9. Gao J, Koshio S, Wang W, et al. (2014) Effects of dietary phospholipid levels on growth performance, fatty acid composition and antioxidant responses of dojo loach Misgurnus anguillicaudatus larvae. Aquaculture 426-427, 304-309. 
10. Geurden I, Radünz-Neto J \& Bergot P (1995) Essentiality of dietary phospholipids for carp (Cyprinus carpio L.) larvae. Aquaculture 131, 303-314.

11. Izquierdo MS, Socorro J, Arantzamendi L, et al. (2000) Recent advances in lipid nutrition in fish larvae. Fish Physiol Biochem 22, 97-107.

12. Izquierdo MS \& Koven W (2011) Lipids. In Larval Fish Nutrition, pp. 47-81 [J Holt, editor]. Chichester: Wiley Blackwell, John Wiley and Sons Publishers.

13. Kanazawa A, Teshima S, Inamori S, et al. (1983) Effects of dietary phospholipids on growth of the larval red sea bream and knife jaw. Mem Fac Fish Kagoshima Univ 32, 109-114

14. Seiliez I, Bruant JS, Zambonino-Infante J, et al. (2006) Effect of dietary phospholipid level on the development of gilthead sea bream (Sparus aurata) larvae fed a compound diet. Aquac Nutr 12, 372-378.

15. Taylor JF, Martinez-Rubio L, Del Pozo J, et al. (2015) Influence of dietary phospholipid onearly development and performance of Atlantic salmon (Salmo salar). Aquaculture 448, 262-272.

16. Tocher DR, Bendiksen EA, Campbell PJ, et al. (2008) The role of phospholipids in nutrition and metabolism of teleost fish. Aquaculture 280, 21-34.

17. Cai Z, Feng S, Xiang X, et al. (2016) Effects of dietary phospholipid on lipase activity, antioxidant capacity and lipid metabolism-related gene expression in large yellow croaker larvae (Larimichthys crocea). Comp Biochem Physiol B Biochem Mol Biol 201, 46-52.

18. Hamza N, Silvestre F, Mhetli M, et al. (2010) Differential protein expression profile in the liver of pikeperch (Sander lucioperca) larvae fed with increasing levels of phospholipids. Comp Biochem Physiol D 5, 130-137.

19. Cahu CL, Gisbert E, Villeneuve LAN, et al. (2009) Influence of dietary phospholipids on early ontogenesis of fish. Aquac Res 40, 989-999.

20. Liu J, Caballero MJ, El-Sayed Ali, et al. (2002) Effect of dietary lecithin and eicosapentaenoic acid on growth, survival, stress resistance and lipid transport in gilthead seabream (Sparus aurata). Fish Sci 6, 1165-1172.

21. Saleh R, Betancor MB, Roo J, et al. (2013) Optimum soybean lecithin contents in microdiets for gilthead seabream (Sparus aurata) larvae. Aquac Nutr 19, 585-597.

22. Saleh R, Betancor MB, Roo J, et al. (2013) Optimum krill phospholipids content in microdiets for gilthead seabream (Sparus aurata) larvae. Aquac Nutr 19, 449-460.

23. Geurden I, Charlon N, Marion D, et al. (1997) Influence of purified soybean phospholipids on early development of common carp. Aquac Int 5, 137-149.

24. Izquierdo MS, Tandler A, Salhi M, et al. (2001) Influence of dietary polar lipids quantity and quality on ingestion and assimilation of labelled fatty acids by larval gilthead seabream. Aquac Nutr 7, 153-160.

25. Takeuchi T, Arakawa T, Satoh S, et al. (1992) Supplemental effect of phospholipids and requirement of eicosapentaenoic acid and docosahexaenoic acid for juvenile striped jack. Nipp Suis Gakk 58, 707-713.

26. Geurden I, Marion D, Charlon N, et al. (1998) Comparison of different soybean phospholipidic fraction as dietary supplements for common carp Cyprinus carpio larvae. Aquaculture 161, 213-223.

27. Saleh R, Betancor MB, Roo J, et al. (2015) Effect of krill phospholipids versus soybean lecithin in microdiets for gilthead seabream (Sparus aurata) larvae on molecular markers of antioxidative metabolism and bone development. Aquac Nutr 21, 474-488.
28. Scholfield CR (1981) Composition of soybean lecithin. J Am Oil Chem Soc 58, 889-892.

29. Staňková B, Kremmyda L-S, Tvrziká E, et al. (2013) Fatty acid composition of commercially available nutrition supplements. Czech J Food Sci 31, 242-248.

30. Hamza N, Kestemont P, Ben Khemis I, et al. (2012) Effect of different sources and levels of dietary phospholipids on performances and fatty acid composition of pikeperch (Sander lucioperca) larvae. Aquac Nutr 18, 249-257.

31. Kanazawa A, Teshima S, Inamori S, et al. (1981) Effects of phospholipids on survival rate and incidence of malformation in the larval ayu. Mem Fac Fish Kagoshima Univ 30, 301-309.

32. Gisbert E, Villeneuve L, Zambonino-Infante JL, et al. (2005) Dietary phospholipids are more efficient than neutral lipids for long-chain polyunsaturated fatty acid supply in european sea bass Dicentrarchus labrax larval development. Lipids 40, 609-618.

33. Bell JG, McEvoy LA, Estevez A, et al. (2003) Optimising lipid nutrition in first-feeding flatfish larvae. Aquaculture $\mathbf{2 2 7}$, 211-220.

34. Kjørsvik E, Olsen C, Wold P-A, et al. (2009) Comparison of dietary phospholipids and neutral lipids on skeletal development and fatty acid composition in Atlantic cod (Gadus morbua). Aquaculture 294, 246-255.

35. Kjørsvik E, Galloway TF, Estevez A, et al. (2011) Effects of larval nutrition on development. In Larval Fish Nutrition, pp. 219-248 [GJ Holt, editor]. Chichester: Wiley-Blackwell.

36. Olsen Y, Evjemo JO, Kjorsvik E, et al. (2014) DHA content in dietary phospholipids affects DHA content in phospholipids of cod larvae and larval performance. Aquaculture $\mathbf{4 2 8}$, 203-214.

37. Salhi M, Hernández-Cruz CM, Bessonart M, et al. (1999) Effect of different polar lipid levels and different $n$-3 HUFA content in polar lipids on gut and liver histological structure of gilthead seabream (Sparus aurata) larvae. Aquaculture 179, 259-263.

38. Caballero MJ, Gallardo G, Robaina L, et al. (2006) Vegetable lipid sources affect in vitro biosynthesis of triacylglycerols and phospholipids in the intestine of sea bream (Sparus aurata). Br J Nutr 95, 448-454.

39. Coutteau P, Geurden I, Camara MR, et al. (1997) Review on the dietary effects of phospholipids in fish and crustacean larviculture. Aquaculture 155, 149-164.

40. Morais S, Cahu C, Zambonino-Infante JL, et al. (2004) Dietary TAG source and level affect performance and lipase expression in larval Sea bass (Dicentrarchus labrax). Lipids 39, 449-458.

41. Saleh R, Betancor MB, Roo J, et al. (2015) Biomarkers of bone development and oxidative stress in gilthead sea bream larvae fed microdiets with several levels of polar lipids and $\alpha$-tocopherol. Aquac Nutr 21, 341-354.

42. Addis MF (2013) Proteomics in foods. In Proteomics in Foods: Principles and Applications, pp. 181-203 [F Toldrá and LML Nollet, editors]. Boston, MA: Springer.

43. Rodrigues PM, Silva TS, Dias J, et al. (2012) Proteomics in aquaculture: applications and trends. J Proteomics $\mathbf{7 5}$, $4325-4345$.

44. Bligh EG \& Dyer WJ (1959) A rapid method for total lipid extraction and purification. Can J Biochem Physiol 37, 911-917.

45. Folch J, Lees M \& Sloane Stanley GH (1957) A simple method for the isolation and purification of total lipides from animal tissues. J Biol Chem 226, 497-509.

46. Menses P \& Glonek T (1988) High resolution ${ }^{31} \mathrm{P}$ NMR of extracted phospholipids. J Lipid Res 29, 679-689. 
47. Nicholson J \& Kim Y (1975) A one-step L-amino acid oxidase assay for intestinal peptide hydrolase activity. Anal Biochem 63, 110.

48. Bessey OA, Lowry OH \& Brock MJ (1946) Rapid coloric method for determination of alkaline phosphatase in five cubic millimeters of serum. J Biol Chem 164, 321-329.

49. Maroux S, Louvard D \& Baratti J (1973) The aminopeptidase from hog-intestinal brush border. Biochim Biophys Acta 321, 282-295.

50. Worthington TM (1982) Enzymes and Related Biochemicals. Biochemical Products Division. NJ: Worthington Diagnostic System Freehold.

51. Cuvier-Péres A \& Kestemont P (2002) Development of some digestive enzymes in Eurasian perch larvae Perca fluviatilis. Fish Physiol Biochem 24, 279-285.

52. Holm H, Hanssen LE, Krogdahl A, et al. (1988) High and low inhibitor soybean meals affect human duodenal proteinase activity differently: in vivo comparison with bovine serum albumin. J Nutr 118, 515-520.

53. Metais P \& Bieth J (1968) Détermination de l' $\alpha$-amylase (Determination of $\alpha$-amylase). Ann Biol Clin 26, 133-142.

54. Gisbert E, Giménez G, Fernández I, et al. (2009) Development of digestive enzymes in common dentex Dentex dentex during early ontogeny. Aquaculture 287, 381-387.

55. Bradford MM (1976) A rapid and sensitive method for the quantitation of microgram quantities of protein utilizing the principle of protein-dye binding. Ann Biochem 72, 248-254

56. Izquierdo MS, Scolamacchia M, Betancor M, et al. (2013) Effects of dietary DHA and alpha-tocopherol on bone development, early mineralisation and oxidative stress in Sparus aurata (Linnaeus, 1758) larvae. Br J Nutr 109, 1796-1805.

57. Vandewalle P, Gluckmann I \& Wagemans F (1998) A critical assessment of the alcian blue/alizarin double staining in fish larvae and fry. Belg J Zool 128, 93-95.

58. Boglione C, Gagliardi F \& Scardi M (2001) Skeletal descriptors and quality assessment in larvae and post-larvae of wildcaught and hatchery-reared gilthead sea bream (Sparus aurata L. 1758). Aquaculture 192, 1-22.

59. Keller A, Nesvizhskii AI, Kolker E, et al. (2002) Empirical statistical model to estimate the accuracy of peptide identifications made by MS/MS and database search. Anal Chem 74, 5383-5392.

60. Nesvizhskii AI, Keller A, Kolker E, et al. (2003) A statistical model for identifying proteins by tandem mass spectrometry. Anal Chem 75, 4646-4658.

61. McCarthy FM, Wang N, Magee GB, et al. (2006) AgBase: a functional genomics resource for agriculture. BMC Genomics 7, 1-13.

62. Roland K, Kestemont P, Hénuset L, et al. (2013) Proteomic responses of peripheral blood mononuclear cells in the European eel (Anguilla anguilla) after perfluorooctane sulfonate exposure. Aquat Tox 128-129, 43-52.

63. Koven WM, Kolkovski S, Tandler A, et al. (1993) The effect of dietary lecithin and lipase, as function of age, on $n-9$ fatty acid incorporation in the tissue lipids of Sparus aurata larvae. Fish Physiol Biochem 10, 357-364.

64. Teshima S, Kanazawa A \& Kakuta Y (1986) Effects of dietary phospholipids on growth and body composition of the juvenile prawn. Nipp Suis Gakk 52, 155-158.

65. Lie O, Sandvin A \& Waagbo R (1993) Influence of dietary fatty acids on the lipid composition of lipoproteins in farmed Atlantic salmon (Salmo salar). Fish Physiol Biochem 12 , 249-260.

66. Hadas E (1998) The influence of dietary phospholipids on feeding rate and absorption of fatty acids in larvae of gilthead seabream (Sparus aurata). MSc thesis, Hebrew University of Jerusalem, Rehovot.

67. Cahu CL, Zambonino Infante J \& Barbosa V (2003) Effect of dietary phospholipid level and phospholipid:neutral lipid value on the development of sea bass (Dicentrarchus labrax) larvae fed a compound diet. Br J Nutr 90, 21-28.

68. Sandel E, Nixon O, Lutzky S, et al. (2010) The effect of dietary phosphatidylcholine/phosphatidylinositol ratio on malformation in larvae and juvenile gilthead sea bream (Sparus aurata). Aquaculture 304, 42-48.

69. Sargent JR, Tocher DR \& Bell JG (2002) The lipids. In Fish Nutrition, 3rd ed., pp. 181-257 [JE Halver and RW Hardy, editors]. San Diego, CA: Elsevier.

70. Wold P-A, Reitan KH, Cahu CL, et al. (2009) Comparison of dietary phospholipids and neutral lipids: effects on gut, liver and pancreas histology in Atlantic cod (Gadus morbua L.) larvae. Aquac Nutr 15, 73-84.

71. Cahu C, Zambonino Infante J \& Takeuchi T (2003) Nutritional components affecting skeletal development in fish larvae. Aquaculture 227, 254-258.

72. Cahu CL, Rønnestad I, Grangier V, et al. (2004) Expression and activities of pancreatic enzymes in developing sea bass larvae (Dicentrarchus labrax) in relation to intact and hydrolyzed dietary protein; involvement of cholecystokinin. Aquaculture 238, 295-308.

73. Cahu CL \& Zambonino-Infante JL (1994) Early weaning of sea bass (Dicentrarchus labrax) larvae with a compound diet: effect on digestive enzyme. Comp Biochem Physiol A 109, 213-222.

74. MacQueen LR, Homme JM, Lie $\varnothing$, et al. (2003) Three different lipid sources in formulated start feeds for turbot (Scophthalmus maximus, L.) larvae, effect on growth and mitochondrial alteration in enterocytes. Aquaculture 1, $33-42$.

75. Ribeiro L, Zambonino-Infante JL, Cahu C, et al. (2002) Digestive enzyme profile of Solea senegalesis post-larvae fed Artemia and compound diet. Fish Physiol Biochem 27, 61-69.

76. Hamza N, Ostaaszewska T \& Kestemont P (2015) Development and functionality of the digestive system in percid fishes early life stages. In Biology and Culture of Percid Fishes: Principles and Practices, pp. 239-264 [P Kestemont, $\mathrm{K}$ Dabrowski and RC Summerfelt, editors]. Dordrecht: Springer Science + Business Media B.V.

77. Shintani T, Takahashi N, Fushiki T, et al. (1995) Recognition system for dietary fatty acids in the rat small intestine. Biosci Biotech Biochem 59, 1428-1432.

78. Zhao J, Ai Q, Mai K, et al. (2013) Effects of dietary phospholipids on survival, growth, digestive enzymes and stress resistance of large yellow croaker, Larmichthys crocea larvae. Aquaculture 410-411, 122-128.

79. Kamaszewski M, Ostaszewska T, Prusińska M, et al. (2014) Effects of Artemia sp. Enrichment with essential fatty acids on functional and morphological aspects of the digestive system in Acipenser gueldenstaedtii larvae. Turk J Fish Aquat Sci 14, 929-938.

80. Drossou A (2006) CCK concentration and tryptic activity in early stages of finfish larvae. PhD thesis, Leibniz Institut für Meereswissenschaften IFM-GEOMAR, Christian-AlbrechtsUniversität Kiel.

81. Rønnestad I, Yufera M, Ueberschar B, et al. (2013) Feeding behaviour and digestive physiology in larval fish: current knowledge, and gaps and bottlenecks in research. Aquaculture 5, Suppl. 1, S59-S98.

82. Lazo JP, Mendoza R, Holt GJ, et al. (2007) Characterization of digestive enzymes during larval development of red drum (Sciaenops ocellatus). Aquaculture 265, 194-205. 
83. Pérez-Casanova JC, Murray HM, Gallant JW, et al. (2006) Development of the digestive capacity in larvae of haddock (Melanogrammus aeglefinus) and Atlantic cod (Gadus morbua). Aquaculture 251, 377-401.

84. Zambonino Infante JL \& Cahu C (2001) Ontogeny of the gastrointestinal tract of marine fish larvae. Comp Biochem Physiol 130, 477-487.

85. Zambonino Infante JL \& Cahu C (2007) Dietary modulation of some digestive enzymes and metabolic processes in developing marine fish: applications to diet formulation. Aquaculture 268, 98-105.

86. Hannah VC, Ou J, Luong A, et al. (2001) Unsaturated fatty acids down-regulate srebp isoforms $1 \mathrm{a}$ and $1 \mathrm{c}$ by two mechanisms in HEK-293 cells. J Biol Chem 276, 4365-4372.

87. Yahagi N, Shimano H, Hasty AH, et al. (1999) A crucial role of sterol regulatory element-binding protein-1 in the regulation of lipogenic gene expression by polyunsaturated fatty acids. J Biol Chem 274, 35840-35844.

88. Georgiadi A \& Kersten S (2012) Mechanisms of gene regulation by fatty acids. Adv Nutr 3, 127-134.

89. Chakravarthy MV, Lodhi IJ, Yin L, et al. (2009) Identification of a physiologically relevant endogenous ligand for PPARalpha in liver. Cell 138, 476-488.

90. Bloj B \& Zilversmit DB (1977) Rat liver proteins capable of transferring phosphatidylethanolamine. Purification and transfer activity for other phospholipids and cholesterol. I Biol Chem 252, 1613-1619.

91. Vahouny GV, Chanderbhan R, Kharroubi A, et al. (1987) Sterol carrier and lipid transfer proteins. Adv Lipid Res 22, 83-113.

92. Bloj B \& Zilversmit DB (1981) Accelerated transfer of neural glycophingolipids and ganglioside GM1 by a purified lipid transfer protein. J Biol Chem 256, 5988-5991.

93. Kowalik D, Haller F, Adamski J, et al. (2009) In search for function of two human orphan SDR enzymes: hydroxysteroid dehydrogenase like 2 (HSDL2) and short-chain dehydrogenase/reductase-orphan (SDR-O). J Steroid Biochem Mol Biol 117, 117-124.

94. Seedorf U, Brysch P, Engel T, et al. (1994) Sterol carrier protein- $\mathrm{x}$ is peroxisomal 3-oxoacyl coenzyme-A thiolase with intrinsic sterol carrier and lipid transfer activity. $J$ Biol Chem 269, 21277-21283.

95. Wouters FS, Bastiaens PI, Wirtz KW, et al. (1998) FRET microscopy demonstrates molecular association of nonspecific lipid transfer protein (nsL-TP) with fatty acid oxidation enzymes in peroxisomes. Embo J 17, 7179-7189.

96. Dansen TB, Kops GJPL, Denis S, et al. (2004) Regulation of sterol carrier protein gene expression by the forkhead transcription factor FOXO3a. J Lipid Res 45, 81-88.

97. Edqvist A, Rebetz J, Jaras M, et al. (2006) Detection of cell cycle- and differentiation stage-dependent human telomerase reverse transcriptase expression in single living cancer cells. Mol Ther 14, 139-148.

98. Berger J \& Moller DE (2002) The mechanisms of action of PPARs. Annu Rev Med 53, 409-435.

99. Gallegos AM, Atshaves BP, Storey SM, et al. (2001) Gene structure, intracellular localization, and functional roles of sterol carrier protein-2. Prog Lipid Res 40, 498563.

100. Zou S, Meng X, Meng Y, et al. (2015) Microarray analysis of anti-cancer effects of docosahexaenoic acid on human colon cancer model in nude mice. Int J Clin Exp Med 8, 5075-5084.

101. Noiva R (1999) Protein disulfide isomerase: the multifunctional redox chaperone of the endoplasmic reticulum. Semin Cell Dev Biol 10, 481-493.

102. Turano C, Coppari S, Altieri F, et al. (2002) Proteins of the PDI family: unpredicted non-ER locations and functions. J Cell Physiol 193, 154-163.

103. Ahmed AA, Balogun KA, Bykova NV, et al. (2014) Novel regulatory roles of omega-3 fatty acids in metabolic pathways: a proteomics approach. Nutr Metab 11, 6.

104. Malhotra JD \& Kaufman RJ (2007) The endoplasmic reticulum and the unfolded protein response. Semin Cell Dev Biol 18, 716-731.

105. Okumura M, Kadokura H \& Inaba K (2015) Structures and functions of protein disulfide isomerase family members involved in proteostasis in the endoplasmic reticulum. Free Radical Biol Med 83, 314-322.

106. Dorner AJ, Wasley LC, Raney P, et al. (1990) The stress response in Chinese hamster ovary cells. Regulation of ERp72 and protein disulfide isomerase expression and secretion. J Biol Chem 265, 22029-22034.

107. Zhu G \& Lee AS (2015) Role of the unfolded protein response, GRP78 and GRP94 in organ homeostasis. J Cell Physiol 230, 1413-1420.

108. Marzec M, Eletto D \& Argon Y (2012) GRP94: An HSP90-like protein specialized for protein folding and quality control in the endoplasmic reticulum. Biochim Biophys Acta 1823, 774-787.

109. Kontara EKM, Coutteau P \& Sorgeloos P (1997) Effect of dietary phospholipid on requirements for and incorporation of $n-3$ highly unsaturated fatty acids in postlarval Penaeus japonicus Bate. Aquaculture 158, 305-320.

110. Ciechanover A \& Brundin P (2003) The ubiquitin proteasome system in neurodegenerative diseases: sometimes the chicken, sometimes the egg. Neuron 40, 427-446.

111. Sveinsdóttir H, Vilhelmsson O \& Gudmundsdóttir Á (2008) Proteome analysis of abundant proteins in two age groups of early Atlantic cod (Gadus morhua) larvae. Comp Biochem Physiol D 3, 243-250. 